\title{
Variability of aerosol optical properties in the Western Mediterranean Basin
}

\author{
M. Pandolfi, M. Cusack, A. Alastuey, and X. Querol \\ Institute of Environmental Assessment and Water Research (IDAEA-CSIC), Barcelona, Spain \\ Received: 18 February 2011 - Published in Atmos. Chem. Phys. Discuss.: 9 May 2011 \\ Revised: 26 July 2011 - Accepted: 5 August 2011 - Published: 10 August 2011
}

\begin{abstract}
Aerosol light scattering, absorption and particulate matter (PM) concentrations were measured at Montseny, a regional background site in the Western Mediterranean Basin (WMB) which is part of the European Supersite for Atmospheric Aerosol Research (EUSAAR). Off line analyses of $24 \mathrm{~h}$ PM filters collected with Hi-Vol instruments were performed for the determination of the main chemical components of PM. Mean scattering and hemispheric backscattering coefficients (@635 nm) were 26.6 $23.2 \mathrm{Mm}^{-1}$ and $4.3 \pm 2.7 \mathrm{Mm}^{-1}$, respectively and the mean aerosol absorption coefficient (@637 nm) was $2.8 \pm 2.2 \mathrm{Mm}^{-1}$. Mean values of Single Scattering Albedo (SSA) and Ångström exponent (å) (calculated from $450 \mathrm{~nm}$ to $635 \mathrm{~nm}$ ) at MSY were $0.90 \pm 0.05$ and $1.3 \pm 0.5$ respectively. A clear relationship was observed between the $\mathrm{PM}_{1} / \mathrm{PM}_{10}$ and $\mathrm{PM}_{2.5} / \mathrm{PM}_{10}$ ratios as a function of the calculated Angström exponents. Mass scattering cross sections (MSC) for fine mass and sulfate at $635 \mathrm{~nm}$ were $2.8 \pm 0.5 \mathrm{~m}^{2} \mathrm{~g}^{-1}$ and $11.8 \pm 2.2 \mathrm{~m}^{2} \mathrm{~g}^{-1}$, respectively, while the mean aerosol absorption cross section (MAC) was $10.4 \pm 2.0 \mathrm{~m}^{2} \mathrm{~g}^{-1}$. The variability in aerosol optical properties in the WMB were largely explained by the origin and ageing of air masses over the measurement site. The MAC values appear dependent of particles aging: similar to the expected absorption cross-section for fresh emissions under Atlantic Advection episodes and higher under aerosol pollution episodes. The analysis of the Ångström exponent as a function of the origin the air masses revealed that polluted winter anticyclonic conditions and summer recirculation scenarios typical of the WMB led to an increase of fine particles in the atmosphere $(\stackrel{a}{a}=1.5 \pm 0.1)$ while the aerosol optical properties under Atlantic Advection episodes and Saharan dust outbreaks were clearly dominated by coarser particles $(\stackrel{a}{a}=1.0 \pm 0.4)$. The sea breeze played an important role
\end{abstract}

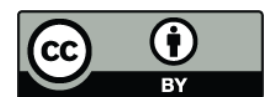

Correspondence to: M. Pandolfi (marco.pandolfi@idaea.csic.es) in transporting pollutants from the developed WMB coastlines towards inland rural areas, changing the optical properties of aerosols. Aerosol scattering and backscattering coefficients increased by around $40 \%$ in the afternoon when the sea breeze was fully developed while the absorption coefficient increased by more than $100 \%$ as a consequence of the increase in the equivalent black carbon concentration (EBC) observed at MSY under sea breeze circulation.

\section{Introduction}

The Mediterranean Basin is a very complex area where orography and atmospheric dynamics coupled with a large variety of aerosol sources give rise to a complex mixture of atmospheric particulate matter (PM). Delimited to the north by the European continent and to the south by the North African arid regions, it is largely affected by Saharan dust, marine aerosols, and anthropogenic emissions from both the highly industrialized/urbanized coastline around the Basin and the European continent. Thus, the Mediterranean represents a unique area in terms of suspended particulate matter (Lelieveld et al., 2002; Ichoku et al., 2002). In order to better understand the role of PM on climate in such complex scenarios, the measurements of aerosol optical properties such as aerosol extinction, absorption, and single scattering albedo (SSA) are needed. In fact, the particles in the atmosphere affect the Earth's climate by cooling or heating the atmosphere depending on their scattering and absorbing properties with respect to the solar and terrestrial radiation. However, the magnitude of the current aerosol effect on climate is very poorly defined given that aerosols are present in the atmosphere in a huge variety of sizes, shapes, chemical composition, refractive index, etc. Fine particles with aerodynamic diameter lower than $1 \mu \mathrm{m}\left(\mathrm{PM}_{1}\right)$ are highly effective in scattering and absorbing solar radiation depending on their chemical composition. Particles which have a net cooling

Published by Copernicus Publications on behalf of the European Geosciences Union. 
effect of the atmosphere and the Earth's surface are sulphate particles which strongly scatter the sun light, while soot particles (or black carbon, BC) have strong absorbing properties over the entire visible spectrum which lead to a warming of the atmosphere. Due to the variety of the regions around the Mediterranean basin, long-term detailed in-situ experiments aimed to the determination of aerosol optical properties are needed. As shown in this work, the in-situ measurements are helpful in order to describe the effects of mesoscale weather systems such as the breeze circulation on aerosol optical properties. A number of studies have been published on in-situ aerosol optical measurements in the Eastern Mediterranean (Vrekoussis et al., 2005; Ichoku et al., 1999; Formenti et al., 2001; Sciare et al., 2005; Kouvarakis et al., 2002; Andreae et al., 2002; Gerasopoulos et al., 2003; Sabbah et al., 2001; Israelevich et al., 2002), Central Mediterranean and South Italy (Pace et al., 2006; Esposito et al., 2004), South Iberian Peninsula (Pereira et al., 2011; Lyamani et al., 2008). However, little has been published on aerosol optical properties in the Western Mediterranean Basin (Mallet et al., 2003; Saha et al., 2008). As evidenced by a number of publications, the WMB undergoes severe pollution episodes affecting not only the coastal sites closest to the emission sources, but also the more elevated rural and remote areas inland due to thermally driven winds (Querol et al., 2007; Pérez et al., 2008a; Pey et al., 2009, 2010; Salameh et al., 2006; Pandolfi et al., 2011). These studies were mainly dedicated to the study of the chemical composition and physical properties of the atmospheric aerosols.

In this study we report $1 \mathrm{yr}$ of simultaneous aerosol optical and chemical properties measured at a regional background site in the WMB. The evolution of aerosol scattering, backscattering and absorption coefficients, Ångström exponent and single scattering albedo are presented and discussed. The relationship of the aerosol optical properties with PM and sulfate concentrations is also discussed. Moreover, the change in aerosol optical properties as a function of both synoptic and meso-to-local transport scenarios is studied.

\section{Methodology}

\subsection{Measurement site}

Simultaneous measurements and sampling of PM levels, chemical composition and optical properties were performed during the period November 2009-October 2010 at Montseny (MSY, 41 ${ }^{\circ} 46^{\prime} 45.63^{\prime \prime} \mathrm{N} 02^{\circ} 21^{\prime} 28.92^{\prime \prime} \mathrm{E}$, $720 \mathrm{~m}$ a.s.l.) a rural site in NE of Spain (Fig. 1). The MSY site is part of the EUSAAR network (European Supersites for Atmospheric Aerosol Research, www.eusaar.net) recently created to integrate the measurements of atmospheric aerosol properties at 21 European ground-based stations. The MSY station is located within a regional natural park about $50 \mathrm{~km}$

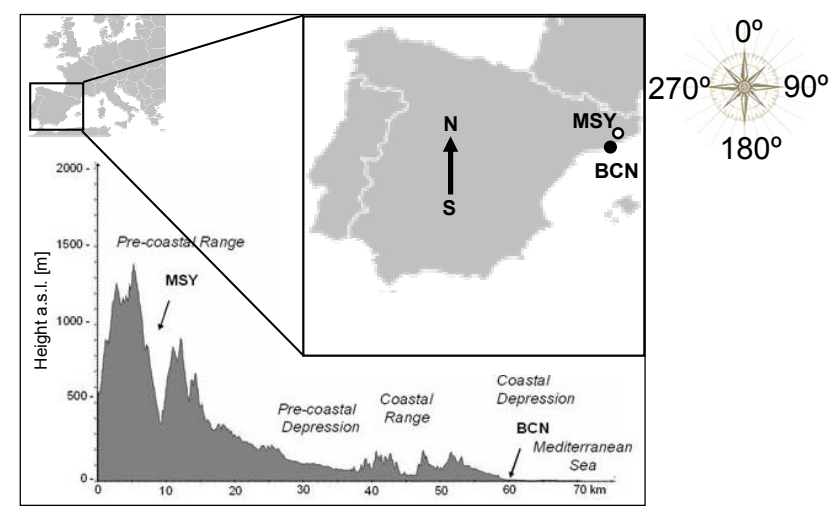

Fig. 1. Location of the Montseny measurement station.

to the NNE of the city of Barcelona (BCN) and $25 \mathrm{~km}$ from the Mediterranean coast. The selected site represents the typical regional background conditions of the WMB characterized by severe pollution episodes affecting not only the coastal sites closest to the emission sources, but also the more elevated rural and remote areas land inwards due to thermally driven winds (Pérez et al., 2008a; Pey et al., 2010). The effect of these particular atmospheric conditions on the aerosol optical properties is discussed in the following paragraphs.

\subsection{Measurements}

Particles scattering $\left(\sigma_{\mathrm{sp}}\right)$ and hemispheric backscattering $\left(\sigma_{\text {bsp }}\right)$ coefficients were measured with a LED-based integrating nephelometer (model Aurora 3000, ECOTECH Pty, Ltd, Knoxfield, Australia). The instrument measures aerosol scattering and backscattering coefficients at $450 \mathrm{~nm}, 525 \mathrm{~nm}$ and $635 \mathrm{~nm}$. A full calibration of the nephelometer was performed three times per year by using $\mathrm{CO}_{2}$ as span gas while zero measurements and adjusts were performed once per week by using internally filtered particle free air. Scattering measurements from nephelometers need to be corrected for truncation errors due to non-ideal detection of scattered radiation. Thus, the experimental setups of nephelometers limit the collection of radiation scattered around both the backward $\left(180^{\circ}\right)$ and forward $\left(0^{\circ}\right)$ directions. The Aurora 3000 for example operates by collecting light scattered within the range $10^{\circ}-170^{\circ}$. A detailed description of the instrument is given by Müller et al. (2011a). Compared to backscatter the main source of error is the truncation in the forward direction $\left(0^{\circ}-10^{\circ}\right)$ where the radiation scattered by particles increases with increasing particle size (van de Hulst, 1957). Thus, the scattering correction factor $\left(\mathrm{C}_{\mathrm{sp}, \lambda}\right)$ is a function of the size of the particles. Moreover, $\mathrm{C}_{\mathrm{sp}, \lambda}$ also includes another source of error which is the non-ideal (non-Lambertian) illumination function of the light source. Müller et al. (2011a) provided parameterized correction factors $\mathrm{C}_{\mathrm{sp}, \lambda}$ as linear relationship of the measured Ångström exponents which are often used for aerosol size characterization and which can 
be easily calculated by means of the multi-wavelength total scattering measurements from nephelometers. Thus, the correction factors were calculated as $C_{\mathrm{sp}, \lambda}=a+b \times \stackrel{a}{a}$. The coefficients $a$ and $b$ at each wavelength were taken from Müller et al. (2011a) while the Ångström coefficients $(\stackrel{\circ}{a})$ were calculated starting from the uncorrected Ecotech scattering data. Similar correction scheme was developed for another commercial nephelometer (TSI model 3563; Anderson et al., 1996) by Anderson and Ogren (1998).

In order to prevent the presence of liquid particles inside the sampling cell, and consequently the effects of hygroscopicity enhancing the scattering properties of particles, a relative humidity $(\mathrm{RH})$ threshold of $60 \%$ was set by using a processor-controlled automatic heater inside the nephelometer. This experimental procedure was applied elsewhere (see for example Pereira et al., 2011 or Anderson and Ogren, 1998). Thus, during the study period the particles were dried to a mean relative humidity of $28 \%$ with a standard deviation of $12 \%$. In their technical paper on Ecotech nephelometer Müller et al. (2011a) dried the sampled aerosols to a RH lower than $25 \%$. Müller et al. (2011a) measured detection limits of Aurora 3000 over a one minute averaging time at wavelengths $450 \mathrm{~nm}, 525 \mathrm{~nm}$, and $635 \mathrm{~nm}$ of $0.11,0.14$, $0.12 \mathrm{Mm}^{-1}$ for total scattering, and $0.12,0.11,0.13 \mathrm{Mm}^{-1}$ for backscattering, respectively.

Aerosol absorption coefficients at $637 \mathrm{~nm}$ (Müller et al., 2011b) and particle number concentrations during the study period were measured with Multi Angle Absorption Photometers (MAAP, model 5012, Thermo) and a Condensation Particle Counters (CPC, Model TSI 3772, D50 $=10 \mathrm{~nm}$ ), respectively. The detection limit of the MAAP instrument is lower than $100 \mathrm{ng} \mathrm{m}^{-3}$ over 2 min integration.

The nephelometer, MAAP and CPC instruments were connected to the same sampling line with the inlet, with a cut-off diameter of $10 \mu \mathrm{m}$, placed at about $1.5 \mathrm{~m}$ above the roof of the cabin hosting the instruments. The inlet flow was $1 \mathrm{~m}^{3} \mathrm{~h}^{-1}$ and humidity control was performed by connecting a drier to the sampling inlet. The Reynolds number for the described inlet was around 1300. In this work the aerosol scattering and backscattering coefficients, equivalent black carbon concentration (EBC) and particle number concentration were integrated over $1 \mathrm{~h}$.

Real time $\mathrm{PM}_{10}, \mathrm{PM}_{2.5}$ and $\mathrm{PM}_{1}$ concentrations were continuously measured, on an hourly basis, by using a GRIMM optical counter (model 1107). Subsequently, the PM concentrations were corrected with factors obtained by comparing real time and gravimetric measurements. $\mathrm{PM}_{x}$ gravimetric measurements on a $24 \mathrm{~h}$ basis were performed twice per week with high volume samplers (DIGITEL and MCV at $\left.30 \mathrm{~m}^{3} \mathrm{~h}^{-1}\right)$ with appropriate $\left(\mathrm{PM}_{1}, \mathrm{PM}_{2.5}, \mathrm{PM}_{10}\right)$ cut-off inlets. Samples were collected on quartz fibre filters and analysed following the experimental procedures described in Querol et al. (2001) for the concentrations of major ( $\mathrm{Al}, \mathrm{Ca}$, $\mathrm{K}, \mathrm{Mg}, \mathrm{Fe}, \mathrm{Ti}, \mathrm{Mn}, \mathrm{P}, \mathrm{S}, \mathrm{Na}$ ) and $\mathrm{NO}_{3}^{-}, \mathrm{SO}_{4}^{2-}, \mathrm{NH}_{4}^{+}$and $\mathrm{Cl}^{-}$ species. In this work the measured concentrations of sulfate were used for comparison with the scattering properties of the aerosols. Levels of elemental carbon (EC) were determined from the collected filters by means of a SUNSET analyzer and subsequently used for the calculation of the mass absorption cross section (MAC) as described in the following paragraphs.

Ambient temperature, relative humidity, pressure, precipitation, wind speed and velocity were measured with a meteorological station placed on the roof of the sampling cabin.

\subsection{Data processing}

The aerosol total scattering $\sigma_{\mathrm{sp}}(\lambda)$ and hemispheric backscattering $\sigma_{\text {bsp }}(\lambda)$ coefficients from nephelometer describe the interaction of light with the particles in the atmosphere as a function of the wavelength. Thus, $\sigma_{\mathrm{sp}}(\lambda)$ is a measure of the elastic diffuse reflection of radiation at all angles $\left(0-360^{\circ}\right)$ while $\sigma_{\text {bsp }}(\lambda)$ represents the radiation elastically scattered by particles back to the direction where the radiation come from. The $\sigma_{\text {bsp }}(\lambda)$ from nephelometer is called hemispheric backscattering given the large angular distribution of the backscattered radiation measured by nephelometers $\left(90^{\circ}\right.$ to $\left.\approx 170^{\circ}\right)$. These optical parameters are function of aerosol properties such as size, shape, composition, refractive index and both are fundamental parameters for estimating the effect of atmospheric aerosol on climate (IPCC, 2007). The ratio hemispheric backscatter-to-scatter can be used to estimate the asymmetry parameter of airborne particles used in radiative transfer calculations (Andrews et al., 2006). The attenuation of light during wave propagation in the atmosphere is determined also by the absorption properties of particles described by the particle absorption coefficient $\sigma_{\text {ap }}(\lambda)$. A major role in absorbing radiation is played by the light-absorbing carbon (LAC; Bond and Bergstrom, 2006) called elemental carbon (EC) or black carbon (BC) depending on the analytical methods used to quantify its atmospheric concentration: thermal/optical techniques for EC and light-absorption measurements for BC (Subramanian et al., 2010). The determination of optical and chemical properties of LAC is important for climate studies as LAC can change its optical properties by absorbing up to $50 \%$ more light if coated with non-absorbing matter such as ammonium sulfate (Bond et al., 2006). The $\sigma_{\mathrm{sp}}(\lambda)$ and $\sigma_{\mathrm{ap}}(\lambda)$ are linked to the concentration of scattering or absorbing particles by their mass scattering cross section (MSC) and mass absorbing cross section (MAC) respectively.

In this work, two additional aerosol optical parameters, the Single Scattering Albedo (SSA) and the Ångström exponent $(\stackrel{a}{)}$, were calculated by using the nephelometer and MAAP data. As known the atmospheric particles have a cooling or warming effect on climate depending on the SSA value. Non-absorbing particles such as sulfate have an SSA of one while lower SSA values indicate the presence of more absorbing particles. The SSA at a given wavelength $\lambda$ is given 
Table 1. Statistics of the considered aerosol components and parameters for the period November 2009 - October 2010 at Montseny site. The wavelength $(\lambda)$ is given in $[\mathrm{nm}]$; Scattering $\left(\sigma_{\mathrm{sp}}\right)$, backscattering $\left(\sigma_{\mathrm{bsp}}\right)$ and absorption coefficients $\left(\sigma_{\mathrm{ap}}\right)$ are given in $\left[\mathrm{Mm}{ }^{-1}\right]$; Backscattering-to-scattering ratio (B/S), single scattering albedo (SSA) and Ångstrom exponent $(\stackrel{a}{a})$ are dimensionless; Equivalent Black Carbon (EBC) and $\mathrm{PM}_{1}$ concentrations are given in $\left[\mu \mathrm{g} \mathrm{m}^{-3}\right]$, and particle number (\#) is given in $\left[\mathrm{cm}^{-3}\right]$. Statistics is based on hourly mean values.

\begin{tabular}{|c|c|c|c|c|c|c|c|c|c|c|c|c|c|}
\hline \multirow{3}{*}{$\begin{array}{c}\text { Hourly base } \\
\sigma_{\mathrm{sp}}\end{array}$} & \multirow{3}{*}{$\begin{array}{c}\lambda \\
450\end{array}$} & \multirow{3}{*}{$\begin{array}{c}\text { Counts } \\
7924\end{array}$} & \multirow{3}{*}{$\begin{array}{l}\text { Mean } \\
42.5\end{array}$} & \multirow{3}{*}{$\begin{array}{l}\mathrm{SD} \\
37.1\end{array}$} & \multirow{3}{*}{$\begin{array}{c}\text { Median (50th perc.) } \\
31.9\end{array}$} & \multirow{3}{*}{$\begin{array}{l}\text { Min } \\
0.2\end{array}$} & \multirow{3}{*}{$\begin{array}{c}\text { Max } \\
332.4\end{array}$} & \multirow{3}{*}{$\begin{array}{c}\text { Skewness } \\
1.82\end{array}$} & \multicolumn{5}{|c|}{ Percentiles } \\
\hline & & & & & & & & & 1 & 10 & 25 & 75 & 99 \\
\hline & & & & & & & & & 2.6 & 7.4 & 14.9 & 59.5 & 163.0 \\
\hline & 525 & 7924 & 34.3 & 30.0 & 25.7 & 0.3 & 270.2 & 1.90 & 2.6 & 6.1 & 12.3 & 47.7 & 134.7 \\
\hline \multirow{4}{*}{$\sigma_{\mathrm{bsp}}$} & 635 & 7924 & 26.6 & 23.2 & 20.2 & 0.3 & 202.2 & 1.88 & 1.8 & 4.7 & 9.8 & 37.2 & 106.4 \\
\hline & 450 & 3989 & 5.7 & 3.4 & 5.3 & 0.2 & 28.2 & 0.85 & 0.8 & 1.6 & 2.9 & 7.8 & 15.0 \\
\hline & 525 & 3981 & 4.9 & 3.0 & 4.5 & 0.3 & 26.5 & 0.91 & 0.5 & 1.2 & 2.4 & 6.7 & 12.9 \\
\hline & 635 & 3919 & 4.3 & 2.7 & 4.0 & 0.3 & 22.8 & 0.81 & 0.4 & 1.1 & 2.2 & 6.0 & 11.4 \\
\hline \multirow[t]{3}{*}{$\mathrm{B} / \mathrm{S}$} & 450 & 3989 & 0.131 & 0.032 & 0.128 & 0.053 & 0.979 & 1.93 & 0.086 & 0.104 & 0.113 & 0.137 & 0.214 \\
\hline & 525 & 3978 & 0.135 & 0.023 & 0.133 & 0.038 & 0.528 & 2.18 & 0.087 & 0.110 & 0.122 & 0.146 & 0.189 \\
\hline & 635 & 3916 & 0.148 & 0.027 & 0.146 & 0.048 & 0.542 & 1.85 & 0.087 & 0.120 & 0.132 & 0.163 & 0.237 \\
\hline$\sigma_{\mathrm{ap}}$ & 637 & 7656 & 2.8 & 2.2 & 2.2 & 0.0 & 34.3 & 2.26 & 0.1 & 0.6 & 1.1 & 3.8 & 10.3 \\
\hline SSA & 635 & 6952 & 0.90 & 0.05 & 0.91 & 0.38 & 1.03 & -2.64 & 0.71 & 0.85 & 0.88 & 0.93 & 0.97 \\
\hline$\stackrel{\circ}{a}$ & $450-635$ & 7834 & 1.33 & 0.48 & 1.41 & -3.01 & 5.19 & -0.55 & -0.03 & 0.72 & 1.13 & 1.59 & 2.38 \\
\hline $\mathrm{EBC}$ & 637 & 7672 & 0.271 & 0.215 & 0.210 & 0.005 & 3.294 & 2.25 & 0.011 & 0.053 & 0.103 & 0.361 & 1.052 \\
\hline $\mathrm{PM}_{1}$ & - & 8110 & 10.1 & 7.5 & 8.5 & 0.0 & 63 & 1.34 & 0.5 & 2.2 & 4.4 & 14.3 & 31.9 \\
\hline \# & - & 5922 & 3682 & 3241 & 2754 & 11 & 34192 & 2.59 & 249 & 954 & 1636 & 4614 & 15469 \\
\hline
\end{tabular}

by:

$$
\operatorname{SSA}(\lambda)=\frac{\sigma_{\mathrm{sp}}(\lambda)}{\sigma_{\mathrm{sp}}(\lambda)+\sigma_{\mathrm{ap}}(\lambda)}
$$

where $\sigma_{\text {ap }}(\lambda)$ is the particles absorption coefficient. Consequently, we calculated the hourly SSA values from equation 1 by using the $\sigma_{\mathrm{sp}}$ at $635 \mathrm{~nm}$ obtained with the nephelometer and the $\sigma_{\text {ap }}$ at $637 \mathrm{~nm}$ measured with the MAAP. It must be taken into account that the information provided by the MAAP is an equivalent black carbon concentration (EBC) which is calculated by the instrument's software by dividing the measured $\sigma_{\text {ap }}(\lambda)$ by $6.6 \mathrm{~m}^{2} \mathrm{~g}^{-1}$ which is the MAC recommended by the manufacturer. Thus, the following equation is applied: $\sigma_{\mathrm{ap}}(\lambda)\left[\mathrm{m}^{-1}\right]=\mathrm{EBC}\left[\mathrm{gm}^{-3}\right] \times \sigma(\lambda)\left[\mathrm{m}^{2} \mathrm{~g}^{-1}\right]$ (Petzold and Schönlinner, 2004) where $\sigma(\lambda)$ is the mass absorption cross section (MAC). Consequently, we calculated the measured absorption coefficient $\sigma_{\mathrm{ap}}(\lambda)$ by multiplying the EBC given by the MAAP by the MAC value of $6.6 \mathrm{~m}^{2} \mathrm{~g}^{-1}$. Then, $\sigma_{\mathrm{ap}}(\lambda)$ and $\sigma_{\mathrm{sp}}(\lambda)$ were used in Eq. (1) for the calculation of SSA.

In order to determine a MAC value more appropriate for the aerosols in the WMB we compared the measured absorption coefficients $\sigma_{\mathrm{ap}}(\lambda)$ with the concentrations of EC in the collected $\mathrm{PM}_{10}$ filters as reported in Fig. 2. The uncertainty for the measured EC concentration was calculated by adding one half of the minimum measured EC concentration to the $10 \%$ of the concentration $\left(\operatorname{Err}_{[E C]}=\min [\mathrm{EC}] / 2\right.$ $+0.1 \cdot[\mathrm{EC}])$. This formula gives higher uncertainty to low EC concentrations (Polissar et al., 1998). An average value of $\sigma(\lambda)=10.4 \pm 2.0 \mathrm{~m}^{2} \mathrm{~g}^{-1}$ was obtained and used to calculate the EBC presented in this work. Absorption cross sections between $7 \mathrm{~m}^{2} \mathrm{~g}^{-1}$ and $11 \mathrm{~m}^{2} \mathrm{~g}^{-1}$ are usually reported in literature (see for example Bond and Bergstrom, 2006; Fernández-Camacho et al., 2010; He et al., 2009; Barnard et al., 2008; Arnott et al., 2003, 2005; Reche et al., 2011)).

The second retrieved aerosol optical parameter was the Ångström exponent $(\stackrel{a}{a})$ which describes the $\lambda$-dependence of particle scattering coefficient and it is given by:

$\stackrel{\circ}{a}=-\frac{\log \left(\sigma_{\mathrm{sp}}^{\lambda_{1}} / \sigma_{\mathrm{sp}}^{\lambda_{2}}\right)}{\log \left(\lambda_{1} / \lambda_{2}\right)}$

An Ångström exponent of 4 represents the scattering from molecules (Rayleigh's regime). Thus, a large $a ̊$ (higher than 2) implies scattering dominated by submicron particles, while $\stackrel{a}{a}$ values lower than one represent an aerosol distribution dominated by coarser particles (Schuster et al., 2006).

\section{Results}

\subsection{General features}

Figure 3 shows the temporal series of the atmospheric components and aerosol parameters measured at MSY station while means, standard deviations, medians, skewness, percentiles, minimum and maximum values were reported in Table 1 . The skewness measures the asymmetry of a distribution function and the higher the skewness, the higher the probability of measuring levels higher than the mean for the considered aerosol component or parameter. All variables reported in Table 1, apart from SSA and $a$, show positive skewness with high values being more frequent than low ones, as 


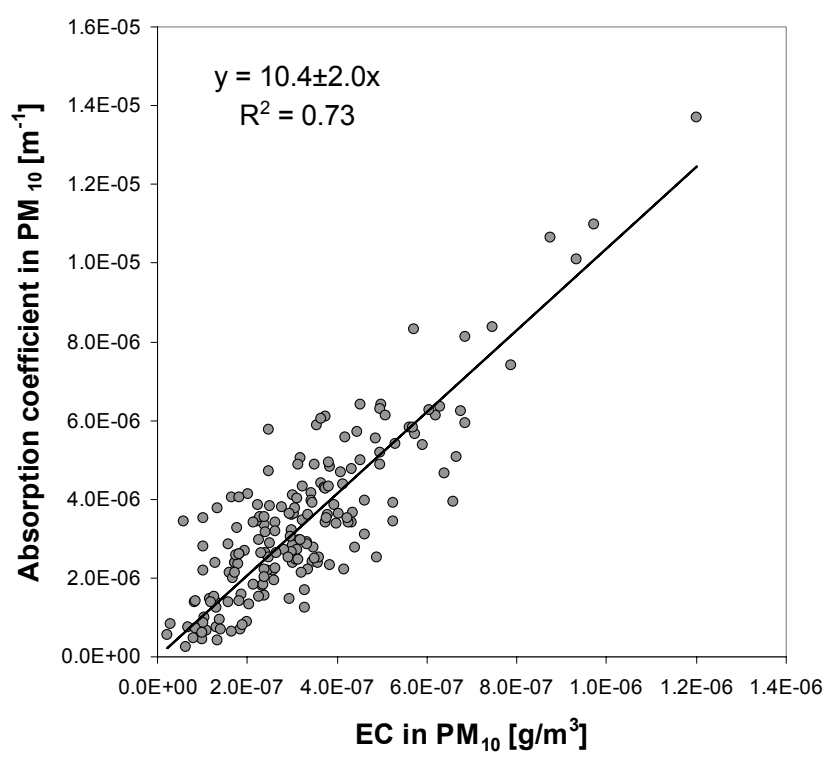

Fig. 2. Correlation between Absorption coefficient from MAAP $(637 \mathrm{~nm})$ and $24 \mathrm{~h}$ off-line elemental carbon (EC) concentrations from $\mathrm{PM}_{10}$ filters.

is typical for many positive defined meteorological parameters (This work, Table 1; O'Neill et al., 2000; Matthias and Bösenberg, 2002; Querol et al., 2009; Pereira et al., 2011). Thus, as shown in Sect. 3.3, a positive skewness leads to a frequency distribution with a tile toward positive values. As already observed, the radiation scattered by particles in the forward direction increases more rapidly than the backscattered radiation with increasing particle size (van de Hulst, 1957). Consequently, there is a higher probability of measuring values much higher than the mean for total scattering compared with backscattering, thus leading to higher skewness for $\sigma_{\mathrm{sp}}$ compared with $\sigma_{\mathrm{bsp}}$ (Table 1). Exceptions from this behaviour were observed for the SSA and the $\stackrel{a}{\text { expo- }}$ nent showing negative skewness indicating the presence of a tile toward values lowers than the mean in the frequency distributions.

Hourly $\mathrm{PM}_{1}$ levels at MSY during the study period (November 2009 - October 2010) ranged between about $2 \mu \mathrm{g} \mathrm{m}^{-3}$ and $63 \mu \mathrm{g} \mathrm{m}^{-3}$ with mean value and standard deviation of $10.1 \pm 7.5 \mathrm{\mu g} \mathrm{m}^{-3}$. As shown later the lowest $\mathrm{PM}_{1}$ levels at MSY were measured under Atlantic Advection episodes typically observed during the cold season in the WMB (Pey et al., 2010) and causing the renovation of accumulated pollution in the aged air masses. Conversely, high $\mathrm{PM}_{1}$ levels were related with both summer regional episodes, characterized by frequent recirculation of air masses and subsequent layering of aerosols over the WMB (Pérez et al., 2004), and winter anticyclonic/accumulation episodes leading to the increase of atmospheric pollution around the emission sources. The winter episodes are recurrently coupled with transport of air masses from Cen-

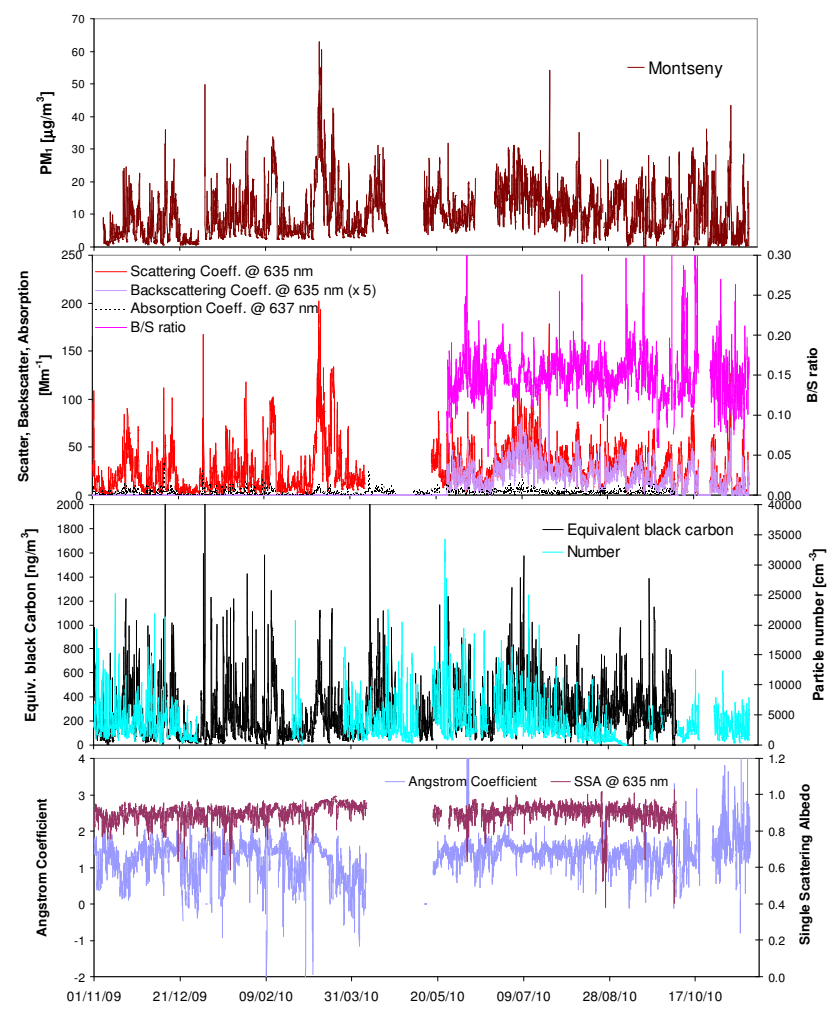

Fig. 3. Temporal series of $\mathrm{PM}_{1}$ concentrations, scattering coefficient $(635 \mathrm{~nm})$, hemispheric backscattering coefficient $(635 \mathrm{~nm})$, absorption coefficient $(637 \mathrm{~nm})$, backscattering-to-scattering ratio $(\mathrm{B} / \mathrm{S})$, equivalent black carbon (EBC) concentrations, particle number, Ångström exponent, and Single Scattering Albedo (SSA) at $635 \mathrm{~nm}$.

tral Europe (Pey et al., 2010). As discussed in the following, of this work these two extreme scenarios (the Atlantic advection and pollution episodes) where characterized by particulate matter with different optical properties. During the measurement period the scattering and hemispheric backscattering coefficients (@635 nm) ranged between $0.4 \mathrm{Mm}^{-1}$ and $202 \mathrm{Mm}^{-1}\left(\right.$ mean $\left.=26.6 \pm 23.2 \mathrm{Mm}^{-1}\right)$ and between $0.3 \mathrm{Mm}^{-1}$ and $23 \mathrm{Mm}^{-1}\left(\right.$ mean $\left.=4.3 \pm 2.7 \mathrm{Mm}^{-1}\right)$ respectively. Hemispheric backscatter measurements were implemented in the used Aurora 3000 nephelometer from the end of May 2010. The aerosol absorption coefficient (@637 nm) ranged between about $0.0 \mathrm{Mm}^{-1}$ and $34 \mathrm{Mm}^{-1}$ with a mean value of $2.8 \pm 2.2 \mathrm{Mm}^{-1}$. Mean values of the measured optical properties at $450 \mathrm{~nm}$ and $525 \mathrm{~nm}$ are reported in Table 1. As reported in literature the aerosol optical properties measured with nephelometers vary substantially depending on the location of the measurement site. Mean values of aerosol absorption and scattering in the visible range of about $60-80 \mathrm{Mm}^{-1}$ and $230-300 \mathrm{Mm}^{-1}$ respectively were registered in large urban areas as Beijing (He et al., 2009) and Mexico City (Silvia, 2002; Paredes-Miranda et al., 2009). Scattering and absorption coefficients with mean values higher than $700 \mathrm{Mm}^{-1}$ and $80 \mathrm{Mm}^{-1}$ respectively 
were measured in a highly polluted site close to New Delhi (Hyvärinen et al., 2010). In Artic remote sites mean scattering and absorption coefficients lower than $10 \mathrm{Mm}^{-1}$ and $1 \mathrm{Mm}^{-1}$, respectively were measured (Aaltonen et al., 2006; Delene and Ogren, 2002). At different locations in the Eastern Mediterranean Basin scattering coefficients at $550 \mathrm{~nm}$ within the range $50-90 \mathrm{Mm}^{-1}$ and absorption coefficients of about 5-6 $\mathrm{Mm}^{-1}$ were registered (Vrekoussis et al., 2005; Gerasopoulos et al., 2003; Andreae et al., 2002). The relatively high values registered in the Western Mediterranean Basin reflected from one side the effect of the Saharan dust events frequently observed in the Mediterranean Basin and from the other side the impact of continental pollution on the Eastern Mediterranean coast. Delene and Ogren (2002) measured values of the absorption, scattering and backscattering coefficients at $550 \mathrm{~nm}$ for $\mathrm{PM}_{10}$ on hourly base ranging between $0.38 \mathrm{Mm}^{-1}$ and $4.62 \mathrm{Mm}^{-1}, 10.4 \mathrm{Mm}^{-1}$ and $57.0 \mathrm{Mm}^{-1}$, and $1.06 \mathrm{Mm}^{-1}$ and $6.63 \mathrm{Mm}^{-1}$, respectively at four regional measurement stations (EEUU, Canada and Alaska). In an urban environment in the South of Spain, scattering and absorption coefficients of $84 \mathrm{Mm}^{-1}$ and $28 \mathrm{Mm}^{-1}$ respectively were measured (Lyamani et al., 2006). Recently, mean scattering and backscattering coefficients of $42.5 \mathrm{Mm}^{-1}$ and $5.9 \mathrm{Mm}^{-1}$ respectively were measured in a small city quite far from pollution sources in the southwestern Portugal (Pereira et al., 2011).

The MSY measurement site can be considered as a regional background site influenced - under specific atmospheric conditions as discussed in the following paragraphs by emissions from the urbanized/industrialized WMB coastline. Mean values of EBC, particle number concentration, SSA and Ångström exponent at MSY during the study period were $271 \pm 215 \mathrm{ng} \mathrm{m}^{-3}, 3682 \pm 3241 \mathrm{~cm}^{-3}, 0.90 \pm 0.05$ and $1.3 \pm 0.5$, respectively. The measured mean SSA and Ångström exponent were found to be consistent with those reported by Mallet et al. (2003) and Saha et al. (2008) respectively for South France. Mean $\mathrm{PM}_{1}, \mathrm{PM}_{2.5}$ and $\mathrm{PM}_{10}$ were $10.1 \pm 7.5 \mu \mathrm{g} \mathrm{m}^{-3}, 13.0 \pm 8.8 \mu \mathrm{g} \mathrm{m}^{-3}$, and $16.6 \pm 11.9 \mu \mathrm{g} \mathrm{m}^{-3}$, respectively. The measured $\mathrm{PM}_{x}$ concentrations were consistent with those typically registered in northeaster Spain (Querol et al., 2008; Pérez et al., 2008a; Pey et al., 2009; Pey et al., 2010). Figure 4 shows the 24 h averaged Ångström exponents as a function of the $\mathrm{PM}_{1}$-to- $\mathrm{PM}_{10}$ and $\mathrm{PM}_{2.5}$-to$\mathrm{PM}_{10}$ ratios. A clear increasing tendency of the $\mathrm{PM}$ ra-

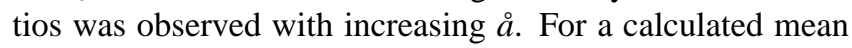
$\stackrel{\circ}{a}$ of 1.3 the daily $\mathrm{PM}_{1} / \mathrm{PM}_{10}$ and $\mathrm{PM}_{2.5} / \mathrm{PM}_{10}$ ratios were found around 0.6 and 0.8 respectively indicating a higher percentage of small particles in the atmosphere compared with coarse particles. As reported in Pereira et al. (2011) about $60-70 \%$ of the light is scattered by submicron particles for an Ångström exponent of 1.5. As shown in the following of this work, the submicron particles dominated even more the light scattering at MSY under specific atmospheric conditions leading to the presence of polluted air masses at MSY station.

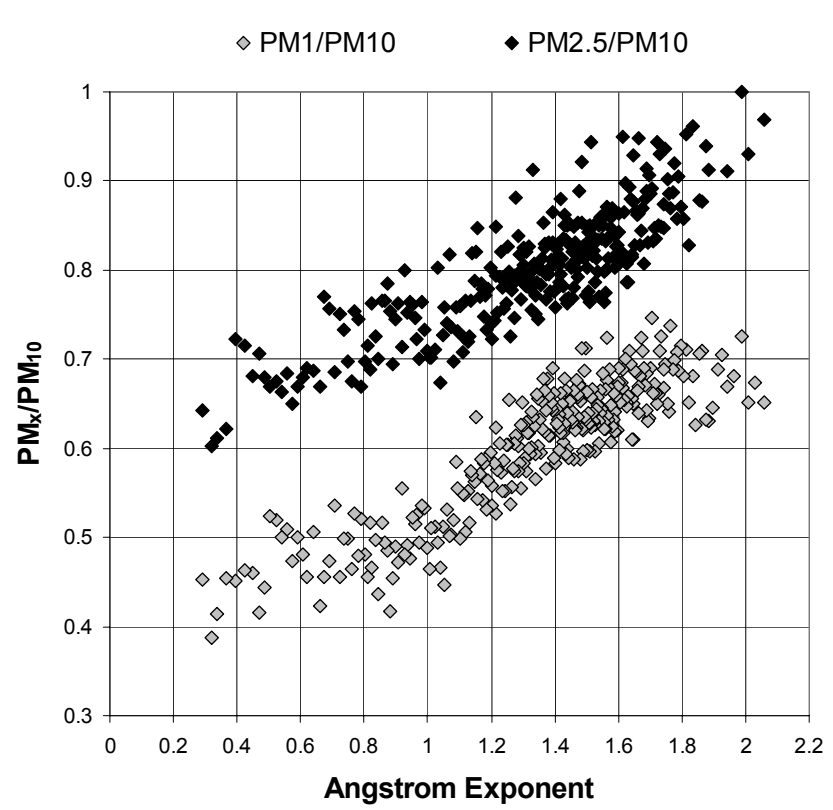

Fig. 4. Correlation between $\mathrm{PM}_{1} / \mathrm{PM}_{10}$ and $\mathrm{PM}_{2.5} / \mathrm{PM}_{10}$ and Ångström exponent.

As suggested by Cermac et al. (2010), negative Ångström exponents could be an indication of reduced anthropogenic emissions with prevalence of coarse-mode particles. Negative Ångström exponent and high Aerosol Optical Depth (AOD) have been also observed and related with transport of coarse-mode dust in northern India by Singh et al. (2004). However, extremely negative values of the Ångström exponents are unfeasible for atmospheric aerosols. Similarly, the Ångström exponent cannot be higher than about 4 which represent the limit given by the Rayleigh regimen for the molecular scattering. In the present case 57 values of the Ångström exponent out of 7834 hourly values were smaller than -1 (0.2 $\%)$ and 5 values were higher than $4(0.1 \%)$. Moreover, Table 1 indicates that the $1^{\text {th }}$ and the $99^{\text {th }}$ percentiles for the Ångström exponent were -0.03 and 2.3 , respectively. Figure 5 shows the distribution of the scattering coefficient at $635 \mathrm{~nm}$ as a function of the calculated hourly Ångström exponents. As reported in the Figure both extremely negative $(<-2)$ and positive $(>4)$ hourly Ångström exponents were always related with low scattering coefficients. A closer analysis of the air mass origin revealed the absence of Saharan dust intrusions during negative $\stackrel{a}{\text { values }}(\stackrel{\circ}{a}<0)$ and the prevalence of Atlantic advection episodes leading to low PM concentrations. The mean $\mathrm{PM}_{10}, \mathrm{PM}_{2.5}$ and $\mathrm{PM}_{1}$ concentrations

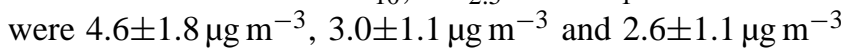
respectively when measuring negative $\stackrel{a}{a}$. Consequently, the measured negative Ångström exponents were likely due to both the presence of relatively larger particles during low aerosol concentration and the instrumental noise under low scattering conditions. Similar behaviour of the Ångström exponent was also observed in a remote subartic site by 


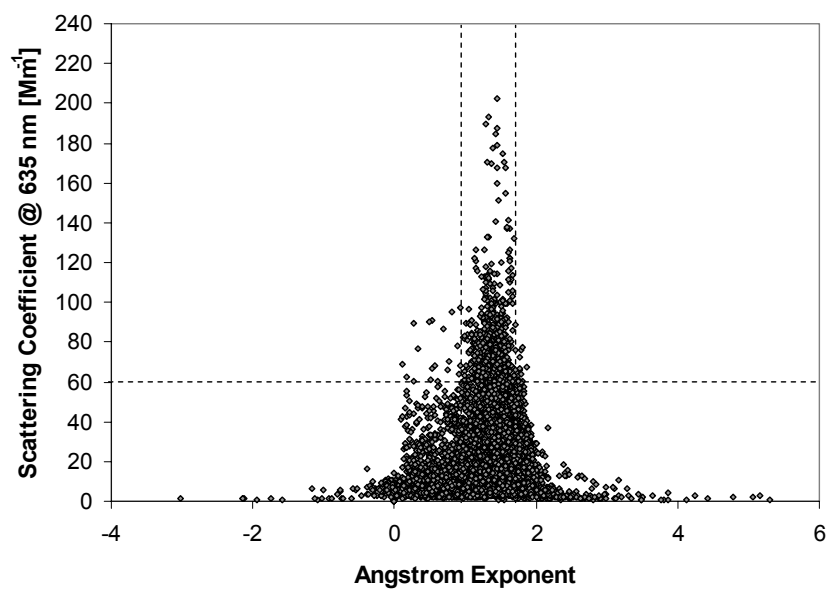

Fig. 5. Scattering coefficient distribution at $635 \mathrm{~nm}$ as a function of the Ångström exponent values.

Aaltonen et al. (2006). Furthermore, the lowest values for single scattering albedos are about 0.2 for pure black carbon (Virkkula et al., 2005) and SSA cannot be higher than 1 by definition of SSA. The 1st and the 99th percentiles for SSA were 0.71 and 0.97 , respectively and only 6 hourly values of the SSA out of $6952(0.09 \%)$ were higher than 1.0. Thus, these extreme SSA values were also related with instrumental noise.

\subsection{Mass scattering cross section for fine mass and $\mathrm{SO}_{4}^{2-}$}

The measurements of aerosol scattering coefficients can be used as a surrogate for fine PM concentrations, thus the scattering of light $\left(\sigma_{\mathrm{sp}}\right)$ is proportional to the particle number density and consequently to the mass of particles in the atmosphere. The relationship between particle number density and mass depends on the physical properties of the aerosol such as size, shape, density, etc. Figure 6a shows the correlation between $\sigma_{\mathrm{sp}}$ at 450,525 , and $635 \mathrm{~nm}$ and $\mathrm{PM}_{1}$ concentrations expressed in $\mu \mathrm{g} \mathrm{m}^{-3}$. Very good correlations were observed with coefficients of determination $\mathrm{R}^{2}$ higher than 0.86 . The slopes of the fitting lines represent the fine mass scattering cross sections (MSC) calculated in $2.8 \pm 0.5 \mathrm{~m}^{2} \mathrm{~g}^{-1}$ at $635 \mathrm{~nm}, 3.6 \pm 0.7 \mathrm{~m}^{2} \mathrm{~g}^{-1}$ at $525 \mathrm{~nm}$ and $4.5 \pm 0.8 \mathrm{~m}^{2} \mathrm{~g}^{-1}$ at $450 \mathrm{~nm}$. The reduction of MSC with increasing wavelength reflects the $\lambda^{-\stackrel{\circ}{a}}$ dependence of $\sigma_{\mathrm{sp}}$ (van de Hulst, 1957; Kokhanovsky, 2008). Values of fine mass scattering cross sections at $550 \mathrm{~nm}$ of $3.8 \mathrm{~m}^{2} \mathrm{~g}^{-1}, 3.4 \mathrm{~m}^{2} \mathrm{~g}^{-1}$, and $4.9 \mathrm{~m}^{2} \mathrm{~g}^{-1}$ were recently measured in Mexico City (Paredes-Miranda et al., 2009), Beijing (Bergin et al., 2001), and India (Mayol-Bracero et al., 2002), respectively. Despite the good correlations observed in Fig. 6a the reported data scattered considerably around the mean given by the fitting lines. This spreading of the data reflects the changes in the microphysical properties of the measured aerosols
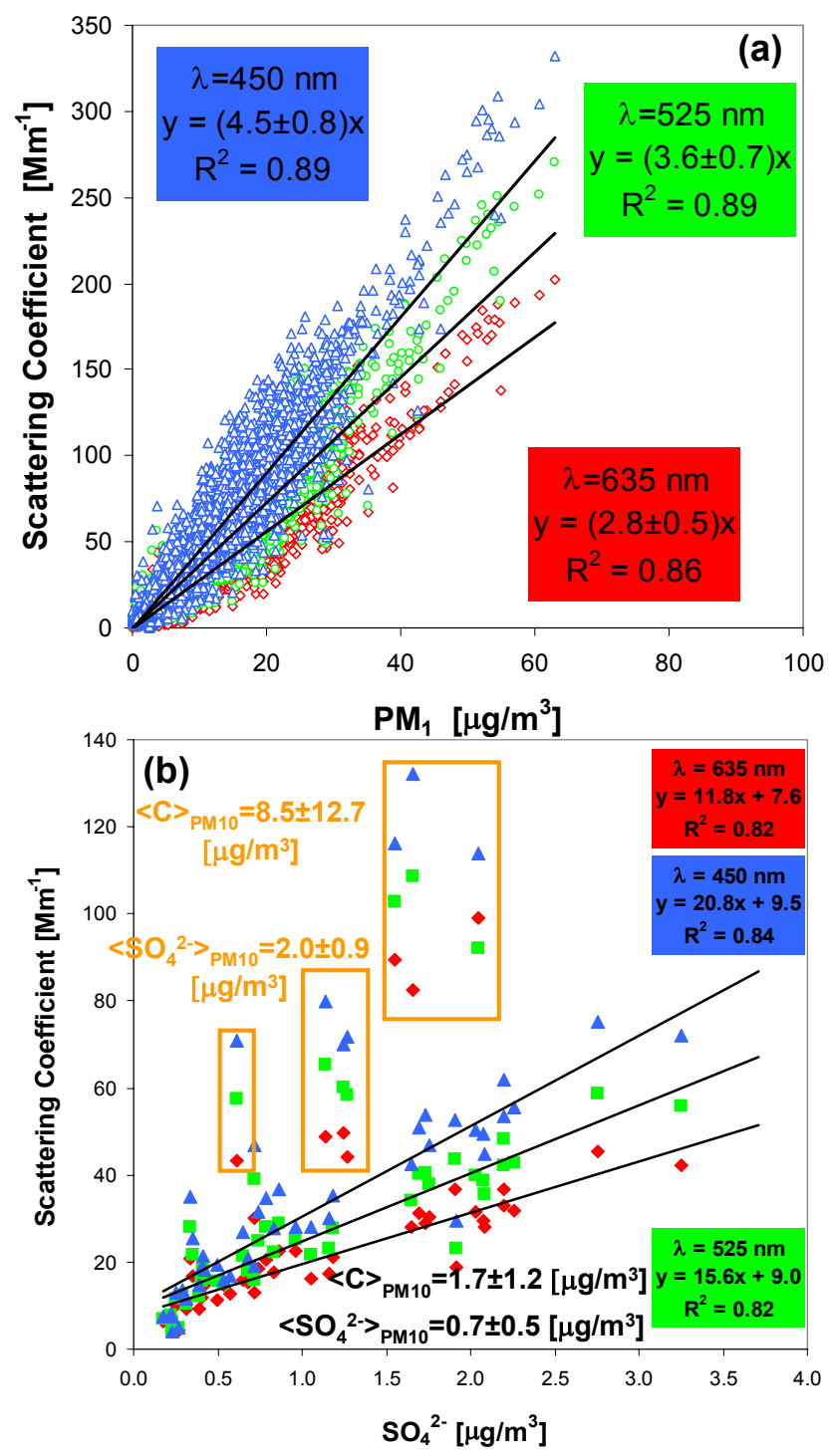

Fig. 6. Correlation between the aerosol scattering coefficients at 450, 525, $635 \mathrm{~nm}$ and PM1 (a) and fine sulfate concentrations (b).

which can occur over a small time-scale. By including the intercepts when fitting the hourly data of Figure 6a (not shown) these intercepts assumed very low values around -3 : $-1 \mathrm{Mm}^{-1}$. Thus, in the hypothetical case of zero PM concentration in the atmosphere also the scattering coefficients approximated, within the errors, to very low values close to the Rayleigh regimen only. Figure $6 \mathrm{~b}$ shows the relationship between the $24 \mathrm{~h}$-averaged $\sigma_{\text {sp }}$ at the three wavelengths and the $24 \mathrm{~h}$-average fine $\left(\mathrm{PM}_{1}\right)$ sulfate concentrations expressed in $\mu \mathrm{g} \mathrm{m}^{-3}$. A good correlation was observed also for fine sulfate particles with $\mathrm{R}^{2}$ higher than 0.82 after excluding specific days highlighted by the orange boxed areas. In these specific days the high measured scattering coefficients were likely due to high concentrations of coarse crustal particles $\left(<\mathrm{C}>\mathrm{PM}_{10}=8.5 \pm 12.7 \mu \mathrm{g} \mathrm{m}^{-3}\right)$ which favoured the 

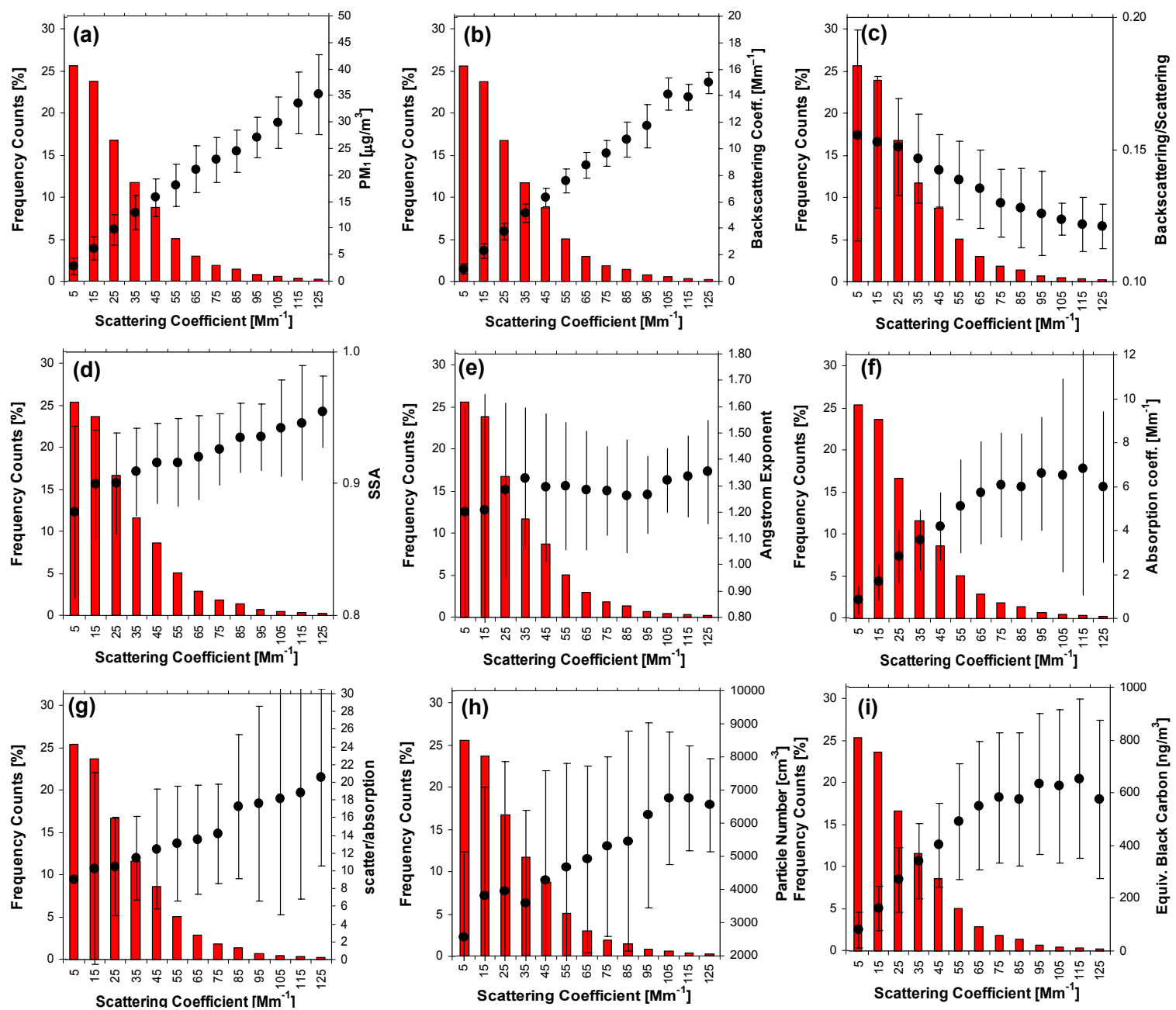

Fig. 7. Correlation between the frequency distribution of aerosol scattering coefficients at $635 \mathrm{~nm}$ and (a) $\mathrm{PM}_{1}$ concentration, (b) backscattering coefficient, (c) backscattering-to-scattering (B/S) ratio, (d) Single Scattering Albedo, (e) Ångström exponent, (f) absorption coefficient, (g) scattering-to-absorption ratio, (h) particle number concentration, and (i) equivalent black carbon concentrations.

adsorption of species like $\mathrm{SO}_{2}$ and the formation of coarse $\mathrm{SO}_{4}^{2-}\left(<\mathrm{SO}_{4}^{2-}>\mathrm{PM}_{10}=2.0 \pm 0.9 \mu \mathrm{g} \mathrm{m}^{-3}\right)$, thus increasing the scattering (Vrekoussis et al., 2005; Adams et al., 2005). In fact, the mean $<\mathrm{C}>\mathrm{PM}_{10}$ and $<\mathrm{SO}_{4}^{2-}>\mathrm{PM}_{10}$ calculated over the points included in the fitting process were $1.7 \pm 1.2 \mu \mathrm{g} \mathrm{m}^{-3}$ and $0.7 \pm 0.5 \mu \mathrm{g} \mathrm{m}^{-3}$, respectively. The $<\mathrm{C}>\mathrm{PM}_{10}$ concentrations were calculated as the sum of $\mathrm{Al}_{2} \mathrm{O}_{3}, \mathrm{SiO}_{2}, \mathrm{CO}_{3}^{2-}, \mathrm{Ca}, \mathrm{Fe}, \mathrm{K}, \mathrm{Mg}, \mathrm{Mn}, \mathrm{Ti}$ and $\mathrm{P}$ (see Querol et al., (2001) for details) and all the points within the orange boxed areas were collected during the period November 2009-April 2010. The fitting lines of Fig. 6b were calculated by adding the y-intercept which indicated a non-zero scattering of light when fine sulfate concentration was close to zero. Thus, even if dominated by fine sulfate particles, the measured scattering of light was due in part to other atmospheric components than fine sulfate thus leading to the observed positive values of the intercepts. MSC for fine sulfate of $11.8 \pm 2.2 \mathrm{~m}^{2} \mathrm{~g}^{-1}$ at $635 \mathrm{~nm}, 15.6 \pm 2.8 \mathrm{~m}^{2} \mathrm{~g}^{-1}$ at $525 \mathrm{~nm}$, and $20.8 \pm 3.4 \mathrm{~m}^{2} \mathrm{~g}^{-1}$ at $450 \mathrm{~nm}$ were calculated (Fig. $6 \mathrm{~b}$ ).

\subsection{Correlation between $\sigma_{\mathrm{sp}}$ and aerosol measurements}

In this section we studied the relationships between $\sigma_{\mathrm{sp}}$ and measured aerosol components or parameters, such as PM mass, backscattering coefficient $\left(\sigma_{\mathrm{bsp}}\right)$, backscatteringto-scattering ratio (B/S ratio), absorption coefficient, SSA, $a ̊$ exponent, EBC concentration, and particle number density (Fig. 7). Similar relationships among aerosol optical properties were investigated by Delene and Ogren (2002). The frequency distribution of hourly $\sigma_{\mathrm{sp}}$ at $635 \mathrm{~nm}$ was calculated for values between $0 \mathrm{Mm}^{-1}$ and $130 \mathrm{Mm}^{-1}$ with a bin of $10 \mathrm{Mm}^{-1}$. Given the low occurrence for $\sigma_{\mathrm{sp}}$ higher than $130 \mathrm{Mm}^{-1}$ (Fig. 5), values higher than $130 \mathrm{Mm}^{-1}$ were 
excluded in this section. First of all it can be noted the log-normal distribution of $\sigma_{\mathrm{sp}}$ (Fig. 7) showing the typical long tile toward positive high values leading to median values lower than the mean and skewness higher than one (Table 1).

As expected a good correlation was observed between $\sigma_{\mathrm{sp}}$ and $\mathrm{PM}_{1}$ concentrations (Fig. 7a), these latter also showing low standard deviations. As the $\sigma_{\mathrm{sp}}$ increased, the $\mathrm{PM}_{1}$ increased monotonically. A similar behaviour was observed for $\sigma_{\text {bsp }}$ and SSA (Fig. $7 \mathrm{~b}$ and d). If the intensity of light scattering increased, also the aerosol backscattering of light increased. However, the relative proportion of scattered and backscattered light (Fig. 7c) was not constant being a function of the amount of scattered light. Thus, as the $\sigma_{\mathrm{sp}}$ values increased the $\mathrm{B} / \mathrm{S}$ values were decreased indicating that the total scattering of aerosols increased faster than the backscatter. Delene and Ogren (2002) also observed this systematic decrease of $\mathrm{B} / \mathrm{S}$ with increasing $\sigma_{\mathrm{sp}}$. This observed behaviour was likely due to the increasing importance of the forward scattering $\left(\theta \sim 0^{\circ}\right)$ compared to backscattering $\left(\theta \sim 180^{\circ}\right)$ when $\sigma_{\mathrm{sp}}$ increased. Furthermore, the decrease in the $\stackrel{a}{a}$ exponent observed as $\sigma_{\mathrm{sp}}$ drops below $35 \mathrm{Mm}^{-1}$ (Fig. 7e) suggests that during low aerosol concentration the MSY measurement site has more relatively larger particles present. This dependence of $\stackrel{a}{a}$ with $\sigma_{\text {sp }}$ was also observed by Delene and Ogren (2002) at two continental stations. Figure $7 \mathrm{f}$ shows that the absorbing properties of the aerosols increased as a function of $\sigma_{\mathrm{sp}}$ as a consequence of the observed increase in EBC mass concentration in the atmosphere with $\sigma_{\text {sp }}$ (Fig. 7i). Thus, following the relationships reported in the Figures $6 \mathrm{a}$ and $7 \mathrm{a}$ for $\sigma_{\mathrm{sp}}$ and $\mathrm{PM}_{1}$, the concentration of EBC is related to the concentration of $\mathrm{PM}_{1}$. However, the observed increasing tendency of SSA with $\sigma_{\mathrm{sp}}$ (Fig. 7d) suggested that the mean scattering properties of the aerosols for a given volume of sampled air increased faster that the absorption properties for the same volume of air (Fig. $7 \mathrm{~g}$ ). Similar results were also presented by Delene and Ogren (2002). Finally, as reported in Fig. 7h the particle number increased with $\sigma_{\mathrm{sp}}$ as expected from Mie theory (van de Hulst, 1957).

\subsection{Diurnal cycles}

The diurnal cycles of the considered aerosol components and parameters measured at MSY is reported in Fig. 8. The diurnal cycle of $\mathrm{PM}_{1}$ concentrations simultaneously measured at an urban background station in Barcelona (the closest big city to MSY station; Fig. 1) is reported for comparison with MSY in order to better interpret the results (Fig. 8a). A detailed description of the Barcelona measuring station is given for example by Pey et al. (2008) and Pérez et al. (2008b). As observed in Fig. 8a the levels at MSY during the $24 \mathrm{~h}$ were driven by the sea breeze which developed from around 09:00 GMT to 18:00 GMT (Fig. 8e) transporting pollutants from the polluted coastline to the remote areas inland (Pey et al., 2010; Pandolfi et al., 2011). The highest $\mathrm{PM}_{1}$ concentrations reaching around $12 \mu \mathrm{g} \mathrm{m}{ }^{-3}$ were measured at MSY under the sea breeze circulation. At the same time the Barcelona monitoring station was cleaned by the sea breeze showing hourly concentrations of $\mathrm{PM}_{1}$ slightly lower than MSY and around $11-12 \mu \mathrm{g} \mathrm{m}^{-3}$ between 13:00 GMT to 17:00 GMT when the sea breeze was fully developed. As reported in Fig. 8e the sea breeze was characterized by an increase in wind velocity which reached $2-3 \mathrm{~m} \mathrm{~s}^{-1}$ between 10:00 GMT and 17:00 GMT. As for the $\mathrm{PM}_{1}$ concentrations, also the aerosol optical properties changed in the late morning-afternoon at MSY. Aerosol scattering and backscattering coefficients increased by around $40 \%$ when the sea breeze was fully developed (13:00-17:00 GMT) if compared with the lower values observed at night-early morning (00:00-08:00 GMT). The scattering coefficient at $635 \mathrm{~nm}$ increased from about $22 \mathrm{Mm}^{-1}$ to $34 \mathrm{Mm}^{-1}$ and the backscattering coefficient from $3.7 \mathrm{Mm}^{-1}$ to $5.2 \mathrm{Mm}^{-1}$. The increase of the absorption coefficient was instead higher and corresponding to about $100 \%$ (from $1.9 \mathrm{Mm}^{-1}$ to $3.9 \mathrm{Mm}^{-1}$ ) as a consequence of the strong increase in EBC concentrations at MSY observed under sea breeze circulation $(\sim 400$ $\mathrm{ng} \mathrm{m}^{-3}$, Figure $8 \mathrm{~d}$ ). Also the particle number concentration increased from values of about $2000-2500 \mathrm{~cm}^{-3}$ in the early morning to more than $6000 \mathrm{~cm}^{-3}$. As a consequence of the increase observed in the values of the absorption coefficient the SSA reduced reaching its minimum value of about 0.88 around 13:00 GMT. The Ångström exponent also changes during the day reflecting the increase in the concentration of fine anthropogenic aerosols in the afternoon at MSY. The minimum measured value was around 1.28 at 07:00 GMT and the highest one of about 1.38 at 13:00 GMT. Thus, during the sea breeze circulation the values of the Ångström exponent increased at MSY indicating a higher load of fine particles in the atmosphere during the day compared with night. In Fig. 8c the diurnal cycle of the Angström exponent calculated from AERONET (the AERosol Robotic NETwork of ground-based sun- and sky-scanning radiometers; see for example Holben et al., 1998) data collected at Barcelona was also reported. The AERONET Ångström exponent was calculated from AOD (aerosol optical depth) data measured at wavelengths of $440 \mathrm{~nm}$ and $675 \mathrm{~nm}$ and only diurnal data were available. Over the study period the mean value of the Ångström exponent at Barcelona was higher than at MSY with a value of $1.4 \pm 0.3$ this being consistent with the higher load of fine aerosols expected at urban level compared with the regional level. Moreover, the two reported Angström exponent's diurnal cycles in Fig. 8c were clearly anti-correlated with low values measured at Barcelona under sea breeze circulation. The possible explanation for the observed reduction of Ångström exponents at BCN were: a) the increase of the concentration of coarser marine aerosol in the atmosphere under sea breeze circulation, and b) the cleansing effect of the breeze over the coastline as also demonstrated by the $\mathrm{PM}_{1}$ diurnal cycle at Barcelona of Figure 8a. Thus, Figure 8 gives a picture of the efficiency of the breeze circulations in polluting remote areas in the WMB and shows that 

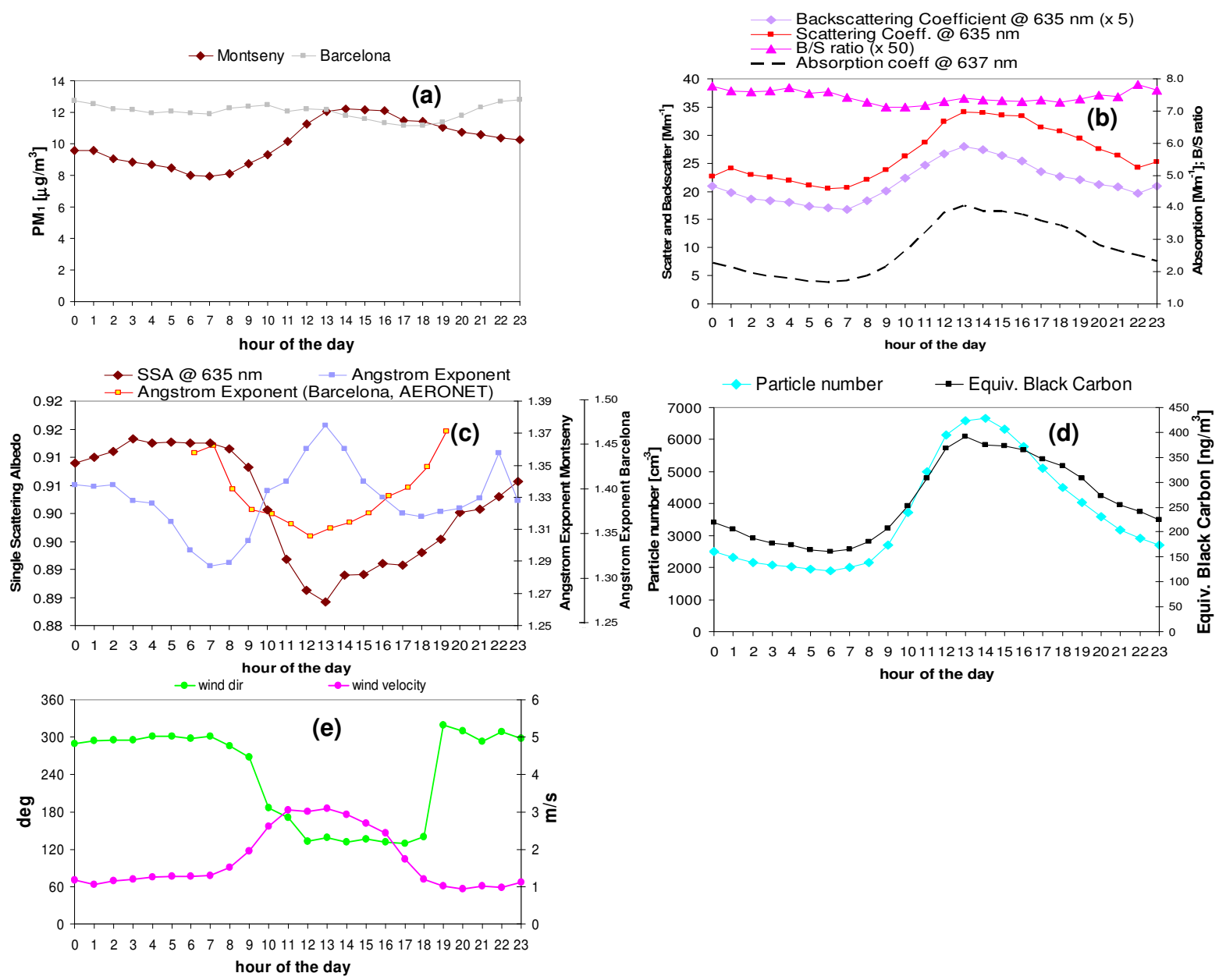

Fig. 8. Diurnal cycles for: (a) $\mathrm{PM}_{1}$ (Montseny and Barcelona), (b) scattering coefficient ( $\left.635 \mathrm{~nm}\right)$, hemispheric backscattering coefficient $(635 \mathrm{~nm})$, absorption coefficient $(637 \mathrm{~nm})$, backscattering-to-scattering ratio (B/S), (c) Ångström exponent and Single Scattering Albedo (SSA) at $635 \mathrm{~nm}$ at Montseny and Ångström exponent from AERONET data at Barcelona (red line); (d) equivalent black carbon and particle number concentrations, and (d) wind speed and velocity.

the anthropogenic pollution affects both the concentrations and the optical properties of PM.

\subsection{Cluster analysis}

In order to interpret the variability of PM optical properties as a function of the main different air mass transports, different meteorological tools and aerosol maps were analyzed: backtrajectories of air masses (HYSPLIT4, Draxler and Rolph, 2003); geopotencial height maps (NOAA/ESRL Physical Sciences Division, Boulder Colorado from their Web site at http://www.cdc.noaa.gov/); aerosol dust concentration maps (BSC/DREAM, NAAPS, and SKIRON); and satellite imagery (NASA-SeaWiFS Project). These tools allowed for the determination of the four main atmospheric scenarios used in this work and affecting the MSY measurement site during the study period. Following the definition given in Pey et al. (2010) these were: (a) Atlantic Advection (AA) episodes
(44 days) with air masses coming from the Atlantic Ocean; (b) Winter anticyclonic episodes (WAE) (25 days) causing the stagnation of air masses around the WMB for a few days and subsequent accumulation of pollutants; (c) Saharan dust intrusions (NAF) (13 days); and (d) Regional episodes (REG) (50 days) mainly recorded in summer and characterized by frequent recirculation of air masses over the WMB (Pérez et al., 2004; Pandolfi et al., 2011). Only clear episodes without precipitations were selected for each category. As reported in Fig. 9 the aerosol components and parameters used in this work show a clear dependence on the origin of air masses. The lowest daily $\mathrm{PM}_{1}$ levels at MSY were measured during AA episodes with mean $\mathrm{PM}_{1}$ concentration of $5.7 \pm 2.8 \mu \mathrm{g} \mathrm{m}^{-3}$. The effect of the Atlantic Advection episodes was to clean the atmosphere reducing the concentration of fine particles in the atmosphere. Consequently, the $\sigma_{\mathrm{sp}}, \sigma_{\mathrm{bsp}}$ and $\sigma_{\mathrm{ap}}$ reached their minimum values during AA with $14.8 \pm 7.8 \mathrm{Mm}^{-1}, 2.8 \pm 0.9 \mathrm{Mm}^{-1}$ and $1.8 \pm 1.0 \mathrm{Mm}^{-1}$, 

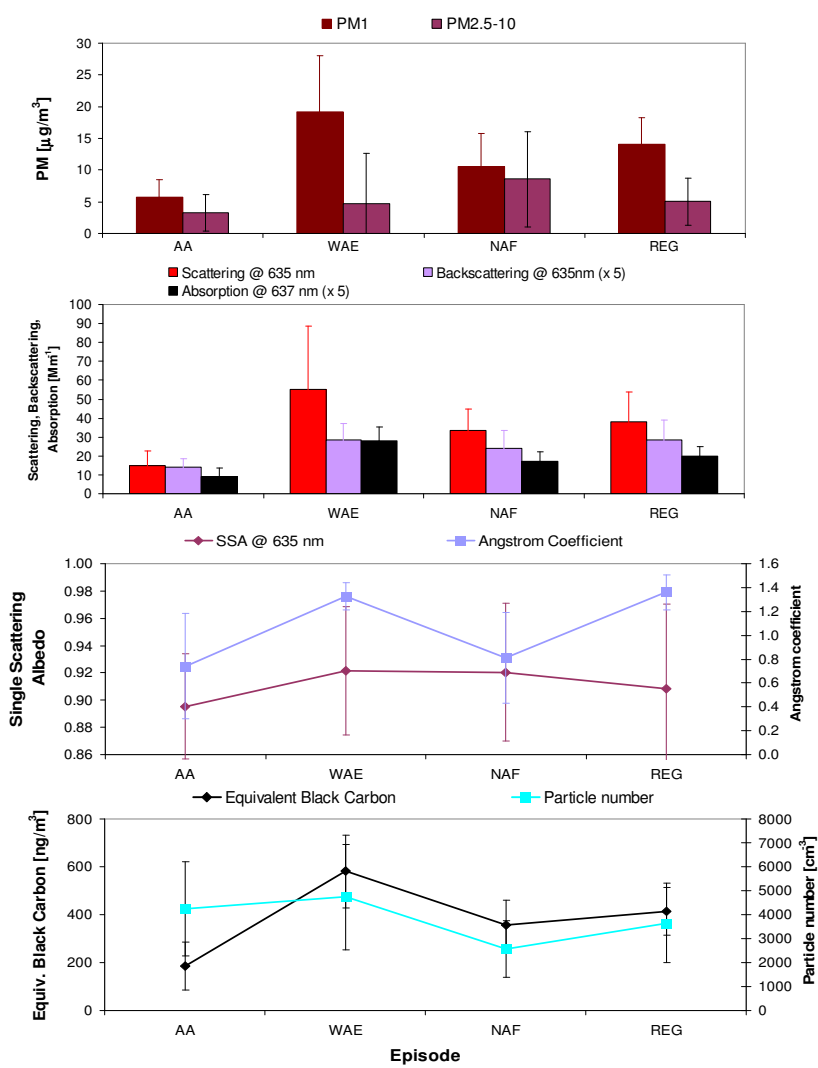

Fig. 9. Aerosol components and parameters as a function of air mass origin: $\mathrm{AA}=$ Atlantic Advection; WAE $=$ Winter Anticyclonic Episode; NAF: Saharan dust outbreaks; REG = Regional stagnation episodes.

respectively. The mean Ångström exponent during AA was $1.0 \pm 0.4$ indicating the prevalence of coarser particles in the atmosphere and the corresponding reduction of the finest particles. Moreover, while EBC concentrations were on average low during AA $\left(\mathrm{EBC}=185 \pm 100 \mathrm{ng} \mathrm{m}^{-3}\right)$ the particle number density was high $\left(4258 \pm 1971 \mathrm{~cm}^{-3}\right)$ as a consequence of the enhanced nucleation in the clean atmosphere. The opposite condition was observed under WAE episodes when the highest $\mathrm{PM}_{1}\left(19.1 \pm 8.8 \mu \mathrm{g} \mathrm{m}^{-3}\right), \sigma_{\mathrm{sp}}\left(55.0 \pm 33.6 \mathrm{Mm}^{-1}\right)$, $\sigma_{\text {bsp }}\left(5.7 \pm 1.7 \mathrm{Mm}^{-1}\right), \sigma_{\text {ap }}\left(5.6 \pm 1.5 \mathrm{Mm}^{-1}\right)$, Ångström exponent $(1.5 \pm 0.1)$, EBC concentration $\left(581 \pm 152 \mathrm{ng} \mathrm{m}^{-3}\right)$ and number concentration $\left(4738 \pm 2203 \mathrm{~cm}^{-3}\right)$ were measured. The values of $\sigma_{\mathrm{sp}}$ and $\sigma_{\mathrm{bsp}}$ under WAE episodes at MSY were similar to the values registered for example by Pereira et al. (2011) in a small city affected by traffic, indicating the importance of specific atmospheric events in polluting remote/rural areas. Thus, relatively high aerosol scattering and absorption coefficients were attributed to the transport, driven by the breeze, of anthropogenic pollution accumulated for few days over the WMB under WAE scenarios reaching the MSY measurement site (Pandolfi et al., 2011). The presence of polluted air masses at MSY with high lev- els of fine particles led to the observed high Ångström exponent indicating that a high percentage of light was scattered by submicron particles. A similar result was obtained under the summer REG episodes ( $(a=1.5 \pm 0.1)$. The REG episodes were characterized by mean PM concentrations lower than during WAE given the higher dilution of PM in summer and the lack of strong inversions typical of the winter period (Pey et al., 2010; Pandolfi et al., 2011). The NAF episodes were characterized by the transport mainly of coarser particles rather than fine particles with measured mean $\mathrm{PM}_{1}$ level $\left(10.5 \pm 5.2 \mu \mathrm{g} \mathrm{m}^{-3}\right)$ lying in the typical range of $\mathrm{PM}_{1}$ levels observed at MSY station (This work; Pey et al., 2010). The Ångström exponent under NAF was $1.0 \pm 0.4$. As reported in Fig. 9, under AA and NAF episodes the relative proportion of coarser $\left(\mathrm{PM}_{2.5-10}\right)$ particles was higher than during WAE and REG episodes thus leading to the observed low Ångström exponent values. Low correlation with air mass origin was observed for the SSA which was almost similar during the four observed scenarios. Despite the increase in the absorption coefficient observed under the WAE scenario, the corresponding increase in $\mathrm{PM}_{1}$ concentration was so high to enhance the mean aerosol scattering properties thus leading to SSA values similar between WAE and AA. Moreover, the absorbing properties of Saharan dust (Vrekoussis et al., 2005) could have accounted, at least in the present case, for the similarity observed between the SSA values during the NAF and WAE episodes.

In order to study the dependence of the mass absorption coefficient (MAC) on the origin of the air masses, the correlation between MAC and EC concentration was analysed as a function of the four defined scenarios. Mass absorption cross sections of $7.5 \pm 1.8 \mathrm{~m}^{2} \mathrm{~g}^{-1}, 10.2 \pm 2.0 \mathrm{~m}^{2} \mathrm{~g}^{-1}$, $10.7 \pm 1.8 \mathrm{~m}^{2} \mathrm{~g}^{-1}$, and $11.6 \pm 2.0 \mathrm{~m}^{2} \mathrm{~g}^{-1}$ at $637 \mathrm{~nm}$ for AA, NAF, REG and WAE scenarios respectively were calculated. Thus, the mass absorption cross sections for NAF, REG and WAE were relatively high and not significantly different, while a statistically-significant difference was observed for the MAC value under AA scenario. The value of MAC estimated under AA is similar to the value proposed by Bond and Bergstrom (2006) of $7.5 \mathrm{~m}^{2} \mathrm{~g}^{-1}$ (at $550 \mathrm{~nm}$ ), or $6.5 \mathrm{~m}^{2} \mathrm{~g}^{-1}$ at $637 \mathrm{~nm}$ assuming a $\lambda^{-1}$ dependence of MAC, for fresh light-absorbing carbon (LAC). As already stated, the AA episodes, from one side, and WAE and REG episodes, from the other side, represent two extremes in terms of degree of pollution in the WMB. The strong winds blowing constantly from the West (from the Atlantic Ocean) under AA episodes assure fresh clean air with low concentrations of pollutants at regional level, while the WAE and REG episodes involve the stagnation (WAE) and recirculation (REG) of air masses around the WMB for a few days with subsequent accumulation of pollutants. Previous studies in the area based on both modelling and experiments showed that this recirculation/accumulation of pollutants can span for more than five days as long as this weather pattern is maintained (Millán et al., 1992; Gangoiti et al., 2001; Pey et al., 2010). 
Consequently, the aerosols transported toward the MSY station under REG and WAE scenarios were mainly aged rather than fresh. As reported in literature (see for example Knox et al., 2009; Bond and Bergstrom, 2006) an increase in mass absorption cross section can be due to difference in coating thickness as a result of the aging of the aerosols. Bond et al. (2006) estimated that absorbing carbon can change its optical properties by absorbing up to $50 \%$ more light if coated with ammonium sulfate (Bond et al., 2006). In our study, mean EC and sulfate concentrations in $\mathrm{PM}_{10}$ filters under WAE and REG scenarios were $0.39 \mu \mathrm{g} \mathrm{m}^{-3}$ and $2.49 \mu \mathrm{g} \mathrm{m}^{-3}$ and $0.27 \mu \mathrm{g} \mathrm{m}^{-3}$ and $3.62 \mu \mathrm{g} \mathrm{m}^{-3}$, respectively. Under the AA scenario mean EC and sulfate were $0.17 \mu \mathrm{g} \mathrm{m}^{-3}$ and $1.04 \mu \mathrm{g} \mathrm{m}^{-3}$ respectively. Thus, higher sulfate concentrations were on average observed under WAE and REG compared with AA, thus probably explaining the observed differences among the calculated MAC values. The relatively high sulfate burden observed under WAE and REG episode could also explain the small variations observed for SSA as a function of the air mass origin. Even if a higher absorption of light was observed under WAE compared to AA, the increase of WAE sulfate concentration enhanced the scattering of light thus probably leading to similar SSA for the WAE and AA scenarios.

\section{Summary and conclusion}

The present work shows how the optical properties of aerosols in rural areas in the Western Mediterranean Basin are highly variable, being dominated not only by the emission sources but also by meteorology. On average, mean values of aerosol scattering, backscattering and absorption coefficients at the regional background station selected for this study (Montseny, NE Spain) were quite low compared with values reported in literature in more industrialized areas or cities around the Mediterranean Basin. However, under specific atmospheric conditions the values of the measured aerosol optical coefficients increased as a consequence of the increase in the concentration of fine particles of anthropogenic origin in the atmosphere. Consequently, also the Single Scattering Albedo (SSA) and the Ångström (å) exponents calculated in this work changed correspondingly. An interesting feature of all these measured parameters was that these were driven by the sea breeze, which develops in the late morning/afternoon transporting polluted air masses from the highly urbanized/indutrialized coastline toward remote areas inland. Thus, the measured aerosol optical coefficients and the calculated SSA and $a$ exponents showed a clear diurnal cycle driven by the sea breeze. Moreover, a high level of variability was observed also as a function of the origin of the air masses. Polluted air masses related with both winter and summer regional conditions of stagnation/accumulation over the study area were linked with an increase in fine particles concentration and an increase in the values of scattering, backscattering and absorption coefficients. On average high a exponents (around 1.5) were measured under these polluted scenarios as a consequence of the increase in the concentration of fine particles. On the contrary a strong reduction in the $\stackrel{a}{a}$ values (around 1.0) were observed under Atlantic Advection episodes and Saharan dust outbreaks indicating that the optical properties of the aerosols were dominated by the coarse mode. The calculated Ångström exponents were also presented as a function of the fine-to-coarse PM ratios. The result was a clear relationship between PM ratios and Ångström exponent. Thus, high Ångström exponents (> 1.4) were clearly related with PM mass dominated by fine particles in the sampled atmosphere. The aerosol absorption cross section (MAC) also changed as a function of the origin of air masses. A mean value of $10.4 \pm 2.0 \mathrm{~m}^{2} \mathrm{~g}^{-1}$ for MAC was calculated during the study period. Relatively small MAC value of $7.5 \pm 1.8 \mathrm{~m}^{2} \mathrm{~g}^{-1}$ at $637 \mathrm{~nm}$ was calculated under Atlantic Advection episodes, while higher MAC $\left(11.6 \pm 2.0 \mathrm{~m}^{2} \mathrm{~g}^{-1}\right)$ was estimated during winter anticyclonic episodes (WAE). The WAE episodes were characterized by an accumulation for a few days of PM and sulfate aerosols over the WMB with consequent ageing of the particles.

Acknowledgements. This study was supported by the Ministry of Science and Innovation (CARIATI CGL2008-06294/CLI, GRACCIE CSD2007-00067), the European Union (6th framework CIRCE IP, 036961, EUSAAR RII3-CT-2006-026140). The authors would also like to acknowledge NASA/Goddard Space Flight Center, SeaWIFS-NASA Project, University of Athens, Navy Research Laboratory-USA and the Barcelona Super-Computing Centre for their contribution with TOMS maps, satellite images, SKIRON dust maps, NAAPs aerosol maps, and DREAM dust maps, respectively. The authors gratefully acknowledge the NOAA Air Resources Laboratory (ARL) for the provision of the HYSPLIT transport and dispersion model and/or READY website (http://www.arl.noaa.gov/ready.html) used in this publication. We also thank José $\mathbf{M}^{a}$. Baldasano and its staff for theirs effort in establishing and maintaining the Barcelona AERONET measurement site.

Edited by: N. Mihalopoulos

\section{References}

Aaltonen, V., Lihavainen, H., Kerminen, V.-M., Komppula, M., Hatakka, J., Eneroth, K., Kulmala, M., and Viisanen, Y.: Measurements of optical properties of atmospheric aerosols in Northern Finland, Atmos. Chem. Phys., 6, 1155-1164, doi:10.5194/acp-6-1155-2006, 2006.

Adams, J. W., Rodriguez, D., and Cox, R. A.: The uptake of $\mathrm{SO}_{2}$ on Saharan dust: a flow tube study, Atmos. Chem. Phys., 5, 26792689, doi:10.5194/acp-5-2679-2005, 2005.

Anderson, T. L., Covert, D. S., Marshall, S. F., Laucks, M. L., Charlson, R. J., Waggoner, A. P., Ogren, J. A., Caldow, R., Holm, R. L., Quant, F. R., Sem, G. J., Wiedensohler, A., Ahlquist, N. A., and Bates, T. S.: Performance characteristics 
of a high-sensitivity, three wavelength, total scatter/backscatter nephelometer, J. Atmos. Ocean. Tech., 13, 967-986, 1996.

Anderson, T. L. and Ogren, J. A.: Determining Aerosol Radiative Properties Using the TSI 3563 Integrating Nephelometer, Aerosol Sci. Tech., 29, 57-69, 1998.

Andreae, T. W., Andreae, M. O., Ichoku, C., Maenhaut, W., Cafmeyer, J., Karnieli, A., and Orlovsky, L.: Light scattering by dust and anthropogenic aerosol at a remote site in the Negev Desert, Israel, J. Geophys. Res., 107(D2), 4008, doi:10.1029/2001JD900252, 2002.

Andrews, E., Sheridan, P. J., Fiebig, M., McComiskey, A., Ogren, J. A., Arnott, P., Covert, D., Elleman, R., Gasparini, R., Collins, D., Jonsson, H., Schmid, B., and Wang, J.: Comparison of methods for deriving aerosol asymmetry parameter, J. Geophys. Res. Atmos., 111, D05S04, doi:10.1029/2004JD005734, 2006.

Arnott, W. P., Moosmüller, H., Sheridan, P. J., Ogren, J. A., Raspet, R., Slaton, W. V., Hand, J. L., Kreidenweis, S. M., and Collett Jr., J. L.: Photoacoustic and Filter-Based Ambient Aerosol Light Absorption Measurements: Instrument Comparisons and the Role of Relative Humidity, J. Geophys. Res., 108(D1), 4034, doi:10.1029/2002JD002165, 2003.

Arnott, W. P., Hamasha, K., Moosmüller, H., Sheridan, P. J., and Ogren, J. A.: Towards Aerosol Light Absorption Measurements with a 7-wavelength Aethalometer: Evaluation with a Photoacoustic Instrument and 3 wavelength Nephelometer, Aerosol Sci. Tech., 39, 17-29, 2005.

Barnard, J. C., Volkamer, R., and Kassianov, E. I.: Estimation of the mass absorption cross 15 section of the organic carbon component of aerosols in the Mexico City Metropolitan Area, Atmos. Chem. Phys., 8, 6665-6679, doi:10.5194/acp-8-6665-2008, 2008.

Bergin, M. H., Cass, G. R., Xu, J., Fang, C., Zeng, L. M., Yu, T., Salmon, L. G., Kiang, C. S., Tang, X. Y., Zhang, Y. H., and Chameides, W. L.: Aerosol radiative, physical, and chemical properties in Beijing during June 1999, J. Geophys. Res., 106(D16), 17969-17980, 2001.

Bond, T. C. and Bergstrom, R. W.: Light absorption by carbonaceous particles: An investigative review, Aerosol Sci. Technol., 40(1), 27-67, doi:10.1080/02786820500421,521, 2006.

Bond, T. C., Habib, G., and Bergstrom, R. W.: Limitations in the enhancement of visible light absorption due to mixing state, J. Geophys. Res.-Atmos., 111(D20), D20211, doi:10.1029/2006JD007315, 2006.

Cermak, J., Wild, M., Knutti, R., Mishchenko, M. I., and Heidinger A. K.: Consistency of global satellite-derived aerosol and cloud data sets with recent brightening observations, Geophys. Res. Lett., 37, L21704, doi:10.1029/2010g1044632, 2010.

Delene, D. J. and Ogren, J. A.: Variability of aerosol optical properties at four North American surface monitoring sites, J. Atmos. Sci., 59, 1135-1149, 2002.

Esposito, F., Leone, L., Pavese, G., Restieri, R., and Serio, C.: Seasonal variation of aerosols properties in South Italy: a study on aerosol optical depths, Ångström turbidity parameters and aerosol size distribution, Atmos. Environ., 38, 1605-1614, 2004.

Fernández-Camacho, R., Rodríguez, S., de la Rosa, J., Sánchez de la Campa, A., Viana, M. M., Alastuey, A., and Querol, X.: Ultrafine particle formation in the inland sea breeze airflow in Southwest Europe, Atmos. Chem. Phys., 10, 9615-9630, doi:10.5194/acp-10-9615-2010, 2010.
Formenti, P., Andreae, M. O., Andreae, T. W., Ichoku, C., Schebeske G., Kettle, J., Maenhaut, W., Ptasinsky, J., Karnieli A., and Leliveld, J.: Physical and chemical characteristics of aerosols over the Negev Desert (Israel) during summer 1996, J. Geophys. Res., 106(D5), 4871-4890, 2001.

Gangoiti, G., Millàn, M. M., Salvador, R., and Mantilla E.: LongRange transport and recirculation of pollutants in the western Mediterranean during the project Regional Cycles of Air Pollution in the west-central Mediterranean Area, Atmos. Environ., 35, 6267-6276, 2001.

Gerasopoulos, E., Andreae, M. O., Zerefos, C. S., Andreae, T. W., Balis, D., Formenti, P., Merlet, P., Amiridis, V., and Papastefanou C.: Climatological aspects of aerosol optical properties in Northern Greece, Atmos. Chem. Phys., 3, 2025-2041, doi:10.5194/acp-3-2025-2003, 2003.

He, X., Li, C. C., Lau, A. k. H., Deng, Z. Z., Mao, J. T., Wang, M. H., and Liu, X. Y.: An intensive study of aerosol optical properties in Beijing urban area, Atmos. Chem. Phys., 9, 8903-8915, doi:10.5194/acp-9-8903-2009, 2009.

Holben, B. N., Eck, T. F., Slutsker, I., Tanré, D., Buis, J. P., Setzer, A., Vermote, E., Reagan, J. A., Kaufman, Y. J., Nakajima, T., Lavenu, F., Jankowiak, I., and Smirnof, A.: AERONET - A federated instrument network and data archive for aerosol characterization, Remote Sens. Environ., 66(1), 1-16, 1998.

Hyvärinen, A.-P., Lihavainen, H., Komppula, M., Panwar, T. S., Sharma, V. P., Hooda, R. K., and Viisanen, Y.: Aerosol measurements at the Gual Pahari EUCAARI station: preliminary 25 results from in-situ measurements, Atmos. Chem. Phys., 10, 72417252, doi:10.5194/acp-10-7241-2010, 2010.

Ichoku, C., Andreae, M. O., Andreae, T. W., Meixner, F. X., Schebeske, G., Formenti, P., Maenhaut, W., Cafmeyer, J., Ptasisnski, J., Karnieli, A., Orlovsky, L.: Interrelationships between aerosol characteristics and light scattering during late winter in an eastern Mediterranean arid environment, J. Geophys. Res., 104, 24371-24393, doi:10.1029/1999JD900781, 1999.

Ichoku, C., Chu, D. A., Mattoo, S., Kaufman, Y. J., Remer, L. A., Tanre, D., Slutsker, I., and Holben, B. N.: A spatio-temporal approach for global validation and analysis of MODIS aerosol products, Geophys. Res. Lett., 29, 8006, doi:10.1029/2001GL013206, 2002.

IPCC 2007 in: Climate Change 2007: The Physical Science Basis (Contribution of Working Group I to the Fourth Assessment Report of the Intergovernmental Panel on Climate Change) edited by: Solomon, S., Qin, D. Manning, M., Chen, Z., Marquis, M., Averyt, K. B., Tignor, M., and Miller, H. L., Cambridge Univ. Press, New York, USA, 131-217, 2007.

Israelevich, P. L., Levin, Z., Joseph, J. H., and Ganor, E.: Desert aerosol transport in the Mediterranean region as inferred from the TOMS aerosol index, J. Geophys. Res., 107(D21), 4572, doi:10.1029/2001JD002011, 2002.

Kokhanovsky, A. A.: Light Absorption and Scattering by Particles in the Atmosphere, Chichester, UK, Praxis Publishing Ltd., 1145, 2008.

Kouvarakis, G., Doukelis, Y., Mihalopoulos, N., Rapsomanikis, S., Sciare, J., and Blumthaler, M.: Chemical, physical, and optical characterization of aerosols during PAUR II experiment, J. Geophys. Res., 107(D18), 8141, doi:10.1029/2000jd000291, 2002.

Knox, A., Evans, G. J., Brook, J. R., Yao, X., Jeong, C. H., Godri, K. J., Sabaliauskas, K., and Slowik, J. G.: Mass absorption cross- 
section of ambient black carbon aerosol in relation to chemical age, Aerosol Sci. Technol., 43, 522-532, 2009.

Lelieveld, J., Berresheim, H., Borrmann, S., Crutzen, P. J., Dentener, F. J., Fischer, H., Feichter, J., Flatau, P. J., Heland, J., Holzinger, R., Korrmann, R., Lawrence, M. G., Levin, Z., Markowicz, K. M., Mihalopoulos, N., Minikin, A., Ramanathan, V., de Reus, M., Roelofs, G. J., Scheeren, H. A., Sciare, J., Schlager, H., Schultz, M., Siegmund, P., Steil, B., Stephanoul, E. G., Stier, P., Traub, M., Warneke, C., Williams, J., and Ziereis, H.: Global air pollution crossroads over the Mediterranean, Science, 298, 794-799, 2002.

Lyamani, H., Olmo, F. J., and Alados-Arboledas, L.: Light scattering and absorption properties of aerosol particles in the urban environment of Granada, Spain, Atmos. Environ., 42, 2630-2642, 2008.

Mallet, M., Roger, J.C., Despiau, S., Dubovik, O., and Putaud, J. P.: Microphysical and optical properties of aerosol particles in urban zone during ESCOMPTE, Atmos. Res., 69, 73-97, 2003.

Matthias, V. and Bösenberg, J.: Aerosol climatology for the planetary boundary layer derived from regular lidar measurements, Atmos. Res., 63, 221-245, 2002.

Mayol-Bracero, O. L., Gabriel, R., Andreae, M. O., Kirchsteter, T. W., Novakov, T., Ogren, J., Sheridan, P., and Streets, D. G.: Carbonaceous aerosols over the Indian Ocean during the Indian Ocean Experiment (INDOEX): Chemical characterization, optical properties, and probable sources, J. Geophys. Res., 107(D19), 8030, doi:10.1029/2000JD0039, 2002.

Millán, M. M., Artiñano, B., Alonso, L., Castro, M., FernándezPatier, R., and Goberna, J.: Meso-meteorological Cycles of Air Pollution in the Iberian Peninsula, (MECAPIP), Contract EV4V0097-E, Air Pollution Research Report 44, (Eur No. 14834) CEC-DG XII/E-1, Rue de la Loi, 200, 1040, Bruselas, 219 pp., 1992.

Müller, T., Laborde, M., Kassel, G., and Wiedensolher, A.: Design and performance of a three-wavelenght LED-based total scatter and backscatter integrating nephelometer, Atmos. Meas. Tech., 4, 1291-1303, doi:10.5194/amt-4-1291-2011, $2011 \mathrm{a}$.

Müller, T., Henzing, J. S., de Leeuw, G., Wiedensohler, A., Alastuey, A., Angelov, H., Bizjak, M., Collaud Coen, M., Engstr"om, J. E., Gruening, C., Hillamo, R., Hoffer, A., Imre, K., Ivanow, P., Jennings, G., Sun, J. Y., Kalivitis, N., Karlsson, H., Komppula, M., Laj, P., Li, S.-M., Lunder, C., Marinoni, A., Martins dos Santos, S., Moerman, M., Nowak, A., Ogren, J. A., Petzold, A., Pichon, J. M., Rodriquez, S., Sharma, S., Sheridan, P. J., Teinil, K., Tuch, T., Viana, M., Virkkula, A., Weingartner, E., Wilhelm, R., and Wang, Y. Q.: Characterization and intercomparison of aerosol absorption photometers: result of two intercomparison workshops, Atmos. Meas. Tech., 4, 245-268, doi:10.5194/amt-4-245-2011, 2011b.

O’Neill, N. T., Ignatov, A., Holben, B. N., and Eck, T. F.: The lognormal distribution as a reference for reporting aerosol optical depth statistics; empirical tests using multi-year, multi-site AERONET sunphotometer data, Geophys. Res. Lett., 27(20), 3333-3336, 2000.

Pace, G., di Sarra, A., Meloni, D., Piacentino, S., and Chamard, P.: Aerosol optical properties at Lampedusa (Central Mediterranean). 1. Influence of transport and identification of different aerosol types, Atmos. Chem. Phys., 6, 697-713, doi:10.5194/acp-6-697-2006, 2006.
Pandolfi, M., Querol, X., Alastuey, A., Jimenez, J., Jorba, O., Stohl, A., Comerón, A., Sicard, M., Pey, J, vanDrooge, B., and the DAURE team: Source and origin of PM in the Western Mediterranean Basin: An Overview of the DAURE campaign, Atmos. Chem. Phys. Discuss., in preparation, 2011.

Paredes-Miranda, G., Arnott, W. P., Jimenez, J. L., Aiken, A. C., Gaffney, J. S., and Marley, N. A.: Primary and secondary contributions to aerosol light scattering and absorption in México City during the MILAGRO 2006 campaign, Atmos. Chem. Phys., 9, 3721-3730, doi:10.5194/acp-9-3721-2009, 2009.

Pereira, S. N., Wagner, F., and Silva, A. M.: Seven year of measurements of aerosol scattering properties, near the surface, in the southwestern Iberia Peninsula, Atmos. Chem. Phys., 11, 17-29, doi:10.5194/acp-11-17-2011, 2011.

Pérez, C., Sicard, M., Jorba, O., Comeron, A., and Baldasano, J. M.: Summertime re-recirculations of air pollutants over the NorthEastern Iberian coast observed from systematic EARLINET lidar measurements in Barcelona, Atmos. Environ., 38, 3983-4000, 2004.

Pérez, N., Pey, J., Castillo, S., Viana, M., Alastuey, A., and Querol, X.: Interpretation of the variability of levels of regional background aerosols in the Western Mediterranean, Sci. Total Environ., 407, 527-540, 2008a.

Pérez, N., Pey, J., Querol, X., Alastuey, A., Lopez, J. M., and Viana, M.: Partitioning of major and trace components in $\mathrm{PM}_{10}-\mathrm{PM}_{2.5^{-}}$ $\mathrm{PM}_{1}$ at an urban site in Southern Europe, Atmos. Environ., 42, 1677-1691, 2008b.

Petzold, A. and Schönlinner, M.: Multi-angle absorption photometry - a new method for the measurement of aerosol light absorption and atmospheric black carbon, J. Aerosol Sci., 35, 421-441, 2004.

Pey, J., Rodríguez, S., Querol, X., Alastuey, A., Moreno, T., Putaud, J. P., and Van Dingenen, R.: Variations of urban aerosols in the western Mediterranean, Atmos. Environ., 42, 9052-9062, 2008.

Pey, J., Pérez, N., Castillo, S., Viana, M., Moreno, T., Pandolfi, M., López-Sebastián, J. M., Alastuey, A., and Querol, X.: Geochemistry of regional background aerosols in the Western Mediterranean, Atmos. Res., 94, 422-435, 2009.

Pey, J., Pérez, N., Querol, X., Alastuey, A., Cusack, M., and Reche, C.: Intense winter atmospheric pollution episodes affecting the Western Mediterranean, Sci. Total Environ., 408, 1951-1959, 2010.

Polissar, A. V., Hopke, P. K., Paatero, P., Malm, W. C., and Sisler, J. F.: Atmospheric Aerosol over Alaska 2. Elemental Composition and Sources, J. Geophys. Res., 103, 19045-19057, 1998.

Querol, X., Alastuey, A., Rodríguez, S., Plana, F., Mantilla, E., and Ruiz, C. R.: Monitoring of PM10 and PM2.5 around primary particulate anthropogenic emission sources, Atmos. Environ., 35, 845-858, 2001.

Querol, X., Viana, M., Alastuey, A., Amato, F., Moreno, T., Castillo, S., Pey, J., de la Rosa, J., Sánchez de la Campa, A., Artínano, B., Salvador, P., García Dos Santos, S., FernándezPatier, R., Moreno-Grau, S., Negral, L., Minguillón, M.C., Monfort, E., Gil, J.I., Inza, A., Ortega, L.A., Santamaría, J.M., and Zabalza, J.: Source origin of trace elements in PM from regional background, urban and industrial sites of Spain, Atmos. Environ., 41, 7219-7231, 2007.

Querol, X., Alastuey, A., Moreno, T., Viana, M. M., Castillo, S., Pey, J., Rodríguez, S., Artiñano, B., Salvador, P., Sánchez, M., 
Garcia Dos Santos, S., Herce Garraleta, M. D., Fernandez-Patier, R., Moreno-Grau, S., Negral, L., Minguillón, M. C., Monfort, E., Sanz, M. J., Palomo-Maríg, R., Pinilla-Gil, E., Cuevas, E., de la Rosa, J., and Sánchez de la Campa, A.: Spatial and temporal variations in airborne particulate matter $\left(\mathrm{PM}_{10}\right.$ and $\left.\mathrm{PM}_{2.5}\right)$ across Spain 1999-2005, Atmos. Environ., 42, 3964-3979, 2008.

Querol, X., Pey, J., Pandolfi, M., Alastuey, A., Cusack, M., Pérez, N., Moreno, T., Viana, M., Mihalopoulos, N., Kallos, G., and Kleanthous, S.: African dust contributions to mean ambient $\mathrm{PM}_{10}$ mass-levels across the Mediterranean Basin, Atmos. Environ., 43,4266-4277, 2009.

Reche, C., Querol, X., Alastuey, A., Viana, M., Pey, J., Moreno, T., Rodríguez, S., González, Y., Fernndez-Camacho, R., de la Rosa, J., Dall'Osto, M., Prévôt, A. S. H., Hueglin, C., Harrison, R. M., and Quincey, P.: New considerations for PM, Black Carbon and particle number concentration for air quality monitoring across different European cities, Atmos. Chem. Phys., 11, 6207-6227, doi:10.5194/acp-11-6207-2011, 2011.

Sabbah, I., Ichoku, C., Kaufman, Y. J., and Remer, L.: Full year cycle of desert dust spectral optical thickness and precipitable water vapor over Alexandria, Egypt, J. Geophys. Res., 106, 1830518316, 2001.

Saha, A., Mallet, M., Roger, J. C., Dubuisson, P., Piazzola, J., and Despiau, S.: One year measurements of aerosol optical properties over an urban coastal site: Effect on local direct radiative forcing, Atmos. Res., 90, 195-202, 2008.

Salameh, T., Drobinski, P., Menut, L., Bessagnet, B., Flamant, C., Hodzic, A., and Vautard, R.: Aerosol distribution over the western Mediterranean basin during a Tramontane/Mistral event, Atmos. Chem. Phys. Discuss., 6, 11913-11956, doi:10.5194/acpd6-11913-2006, 2006.

Schuster, G. L., Dubovik, O., and Holben, B. N.: Ångström exponent and bimodal aerosol size distributions, J. Geophys. Res., 111, D07207, doi:101029/2005JD006328, 2006.
Sciare, J., Oikonomou, K., Cachier, H., Mihalopoulos, N., Andreae, M. O., Maenhaut, W., and Sarda-Estve, R.: Aerosol mass closure and reconstruction of the light scattering coefficient over the Eastern Mediterranean Sea during the MINOS campaign, Atmos. Chem. Phys., 5, 2253-2265, doi:10.5194/acp-5-2253-2005, 2005.

Silvia, E. D.: Aerosol impacts on visible light extinction in the atmosphere of Mexico City, Sci. Total Environ., 287, 213-220, 2002.

Singh, R. P., Dey, S., Tripathi, S. N., Tare, V., and Holben, B. N.: Variability of aerosol parameters over Kanpur city, northern India, J. Geophys. Res., 109, D23206, doi:10.1029/2004JD004966, 2004.

Subramanian, R., Kok, G. L., Baumgardner, D., Clarke, A., Shinozuka, Y., Campos, T. L., Heizer, C. G., Stephens, B. B., de Foy, B., Voss, P. B., and Zaveri, R. A.: Black carbon over Mexico: the effect of atmospheric transport on mixing state, mass absorption cross-section, and $\mathrm{BC} / \mathrm{CO}$ ratios, Atmos. Chem. Phys., 10, 219-237, doi:10.5194/acp-10-219-2010, 2010.

van de Hulst, H. C.: Light Scattering by Small Particles, Wiley, NY, USA, 1-126, 1957.

Virkkula, A., Ahlquist, N. C., Covert, D. S., Arnott, W. P., Sheridan, P. J., Quinn, P. K., and Coffman, D. J.: Modification, Calibration and a Field Test of an Instrument for Measuring Light Absorption by Particles, Aerosol Sci. Tech., 39, 68-83, 2005.

Vrekoussis, M., Liakakou, E., Koçak, M., Kubilay, N., Oikonomou, K., Sciare, J., and Mihalopoulos, N.: Seasonal variability of optical properties of aerosols in the eastern Mediterranean, Atmos. Environ., 39, 7083-7094, 2005. 